\title{
Late Palaeozoic to Triassic formations unconformably deposited over the Ronda peridotites (Betic Cordilleras): Evidence for their Variscan time of crustal emplacement
}

\section{Formaciones del Paleozoico superior al Triásico depositadas discordantes sobre las peridotitas de Ronda: Evidencia de su emplazamiento cortical durante el Herciniano}

\author{
C. Sanz de Galdeano ${ }^{1}$, M.D. Ruiz Cruz ${ }^{2}$ \\ 1 Instituto Andaluz de Ciencias de la Tierra (CSIC- Univ. Granada). Facultad de Ciencias. 18071 Granada. Email: csanz@ugr.es \\ 2 Departamento de Química Inorgánica, Cristalografía y Mineralogía. Facultad de Ciencias (Polígono Campus de Teatinos). \\ Univ. de Málaga. 29071 Málaga. Email: mdruiz@uma.es
}

\begin{abstract}
The age of the emplacement of the Ronda Peridotites has been widely debated during recent decades, and ages ranging from the Palaeozoic to the early Miocene have been proposed, although most of the current interpretations suggest an Oligocene-Miocene age. In this article, we describe two meta-sedimentary formations (the lower one formed by detrital sediments and the upper one by marbles) that were unconformably deposited over the Ronda peridotites and now record low-grade metamorphism. The detrital formation contains layers of acidic rocks with an age of $269 \pm 9 \mathrm{Ma}$ and the overlying marbles are assumed to be Triassic. The existence of these unconformable formations over the peridotites is crucial for the dating of the exhumation of the latter. The presence of peridotite clasts in the detrital formation indicates that peridotites were exposed during the Permian and other data suggest that peridotites were exhumed during the late Carboniferous. During the Alpine cycle, the peridotites operated as an element situated at the bottom of the tectonically higher Alpujarride/Sebtide unit (the Jubrique unit) and forming part of it, then being incorporated to the Alpine thrusts of this unit.
\end{abstract}

Keywords: Ronda Peridotites; Alpujarride; Sebtide; Betic Cordillera; zircon.

\section{RESUMEN}

La edad del emplazamiento de las peridotitas de Ronda ha sido discutida ampliamente en las últimas décadas, con hipótesis que van desde el Paleozoico al Mioceno inferior, aunque la mayoría de las interpretaciones actuales sugiere una edad oligo-miocena. En este artículo, describimos la existencia de dos formaciones meta-sedimentarias (la inferior formada originalmente por sedimentos detríticos y la superior por carbonatos) que se depositaron en discordancia sobre las peridotitas de Ronda y ahora registran un grado bajo de metamorfismo. La formación detrítica contiene capas de rocas ácidas con una edad de 269 \pm 9 Ma y los mármoles situados encima se atribuyen al Trías. La existencia de esas dos formaciones es crucial para la datación de la exhumación de las peridotitas.

Recibido el 11 de febrero de 2015 / Aceptado el 20 de octubre de 2015 / Publicado online el 3 de marzo de 2016

Citation / Cómo citar este artículo: C. Sanz de Galdeano \& M.D. Ruiz Cruz (2016). Late Palaeozoic to Triassic formations unconformably deposited over the Ronda peridotites (Betic Cordilleras): Evidence for their Variscan time of crustal emplacement. Estudios Geológicos 72(1): e043. http://dx.doi.org/10.3989/egeol.42046.368.

Copyright: (c) 2016 CSIC. This is an open-access article distributed under the terms of the Creative Commons Attribution-Non Commercial (by-nc) Spain 3.0 License. 
La presencia de clastos de peridotitas en la formación detrítica indica que aquellas estuvieron expuestas durante el Pérmico, otros datos sugieren que las peridotitas fueron exhumadas durante el Carbonífero superior. Durante el ciclo alpino, las peridotitas actuaron como un elemento ya antes situado en la base de la unidad Alpujárride/ Sébtide superior (unidad de Jubrique), formando parte de ésta.

Palabras clave: Peridotitas de Ronda; Alpujárride; Sébtide; Cordillera Bética; zircón.

\section{Introduction}

Orogenic peridotites are variably sized pieces of the upper mantle that are exposed in mountain belts. Consequently, they are unique objects for realistic large-scale models of the Earth's geochemical and tectonic evolution (Griffin et al., 1999) as well as for interpreting the tectonic evolution of particular orogens (Liou et al., 2007 and references therein). Examples include the Caledonian, Variscan, and Alpine orogens of Europe, the Kokchetav Massif of Kazakhstan, and the Triassic Dabie-Sulu terrane in east-central China (for reviews, see Medaris, 1990; Brueckner \& Medaris, 2000; O'Brien, 2000; Liou et al., 2007).

The Ronda (and the Beni Bousera) peridotites form two of the largest outcrops of orogenic peridotites in the world. The time of their crustal emplacement and exhumation is debated, opinions varying from prePalaeozoic to Alpine ages. This matter is important because it directly concerns the geologic evolution of the Betic-Rif Cordilleras and the relative importance of the Variscan and Alpine orogenies. At present, most authors interpret the peridotites as having been exhumed during the Oligocene-Miocene (see Platt et al., 2013 for a Review). This hypothesis, as well as those supporting a Variscan age, is based mainly on: a) petrological and mineralogical studies; b) isotopic dating; and c) tectonic considerations and models explaining the evolution of the Western Mediterranean.

This study presents new data on sedimentological, stratigraphic, and tectonic structures, and new U-PB zircon dating, contributing to a better knowledge of the age of exhumation of the peridotites. The significance of some tectonic units previously defined in this area is discussed and a new model for the evolution of the Cordillera in their western zone is proposed.

\section{Background}

The existence of the Ronda peridotites has been known for many years and several of the first articles are those of Macpherson $(1868,1889)$ and
Orueta (1917). From that time to the present, hundreds of articles have been published, many devoted to the interpretation of their current tectonic position, their lithospheric or crustal emplacement, uplift, and exhumation, with different proposals of ages for the several processes.

In general, most articles related to the Ronda massif in the Betics are based on an exclusive (or almost exclusive) Alpine scenario, whereas most articles devoted to the Beni Bousera massif in the Rif favour a mixed Variscan+Alpine origin. Thus, previous works arguing for the exhumation of the peridotites in early Miocene, reflecting extensional collapse, include: Loomis (1975), Lundeen (1978), and Priem et al. (1979), which are based mainly on K/Ar dating of rocks from the metamorphic aureole around the peridotites; the works of Doblas \& Oyarzun (1989), Van der Wal \& Vissers (1993), Vissers et al. (1995), Tubía (1985, 1994), Tubía \& Cuevas (1986, 1987), Tubía et al. (1997; 2003), Balanyá et al., (1993, 1997), Davies et al. (1993), Sánchez Gómez et al. (1995 a, b; 1999; 2002), Platt et al., 2003, Esteban et al. (2011), Afiri et al. (2011), and Garrido et al. (2011), which used tectonic and petrological criteria derived from the study of peridotites and/or crustal rocks; the works of Zindler et al. (1983) and Reisberg et al. (1989), based on $\mathrm{Sr}$ and Nd isotopic data of clinopyroxenes; and works of Platt \& Whitehouse (1999) and Sanchez-Rodriguez \& Gebauer (2000), based on zircon dating of migmatitic rocks. Précigout et al. (2013) deduced that the Ronda peridotites were emplaced during the OligoceneMiocene just before 22 Ma. Hidas et al. (2013) proposed a model for the emplacement of the Ronda Peridotites in which folding and shearing of an attenuated mantle lithosphere occurred by back arc basin inversion during the late Oligocene and a later collision during the earliest Miocene. Platt et al. (2013) extensively discussed the arguments in favour of and against the possible Variscan or Miocene ages of the exhumation. Also interpreting the exhumation of the peridotites during the early Miocene, but in a thrust-related peridotite emplacement, are the articles of Mazzoli \& Martín-Algarra (2011), and Mazzoli et al. (2013). 
On the whole, in the articles assuming an Alpine emplacement of the peridotites, the proposed ages vary from the Jurassic to the Miocene, with preference for the Oligocene - early Miocene ages. Nevertheless, Kornprobst (1976) described detritus in Silurian to Carboniferous sediments of the Ghomaride complex that are very similar to highgrade metamorphic rocks and ultramafites outcropping in the Beni Bousera district, which would have eroded during the Palaeozoic. Reuber et al. (1982) and Michard et al. (1997) identified two periods of thinning in the Alboran region (western end of the Mediterranean Sea), which might have occurred during the late Variscan extension and Tethyan opening, and during the late Oligocene. Bouybaouène et al. (1998), based on petrological and geochemical data of kinzingites and mafic granulites of the aureole of the peridotites of Beni Bousera, considered their data to be evidence of Variscan metamorphism. Montel et al. (2000) dated crystals of monazite included in garnet and interpreted the age $(284 \pm 27 \mathrm{Ma})$ as corresponding to the HP event that affected the aureole around the peridotites of Beni Bousera. Chalouan et al. (2008) discussed the possible ages of the exhumation of the peridotites without presenting a clear conclusion. Rossetti et al. (2010) reported the occurrence of distinct generations of peraluminous granitic bodies intruded within Beni Bousera peridotites and the overlying crustal rocks during the Variscan ( $\sim 300 \mathrm{Ma})$ and the Alpine ( $22 \mathrm{Ma})$ periods, respectively. Finally, Ruiz Cruz et al. (2011 \& 2012) and Ruiz Cruz \& Sanz de Galdeano (2012, 2103, 2014) argued in favour of a pre-Mesozoic emplacement of the peridotites in the Jubrique and Ceuta zones, using petrological criteria and recent zircon dating.

In relation to the current tectonic position of the peridotites in the western zone of the Betics, and concretely at the $\mathrm{N}$ of Estepona, in Benahavis, and in the valley of the Guadaiza river (Figs. 1, 2, 7, 8, and 9), the commonly accepted interpretation is that

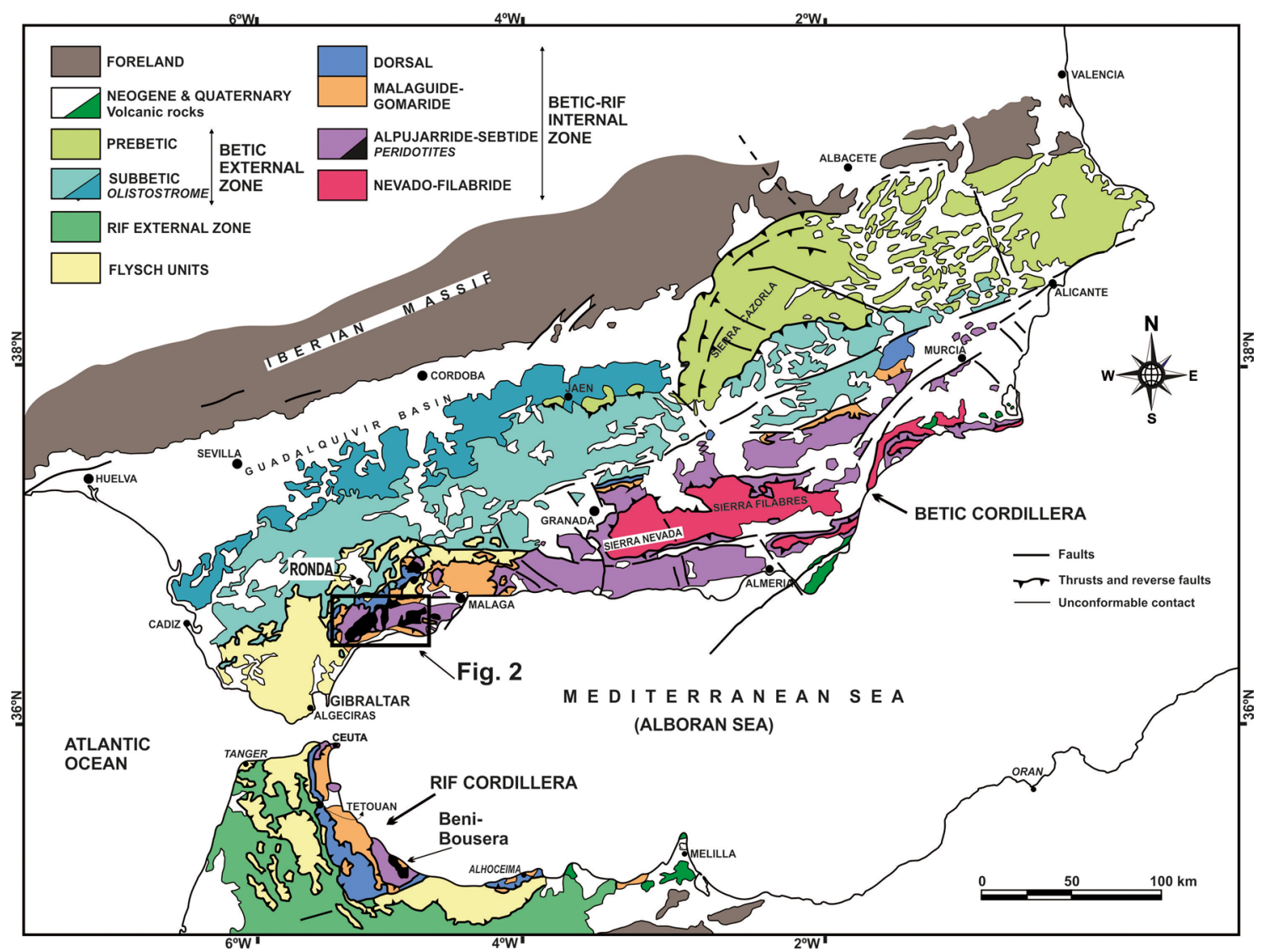

Figure 1.-Geologic map of the Betic and Rif (in part) cordilleras. The area corresponding to Fig. 2 is marked by the square. 


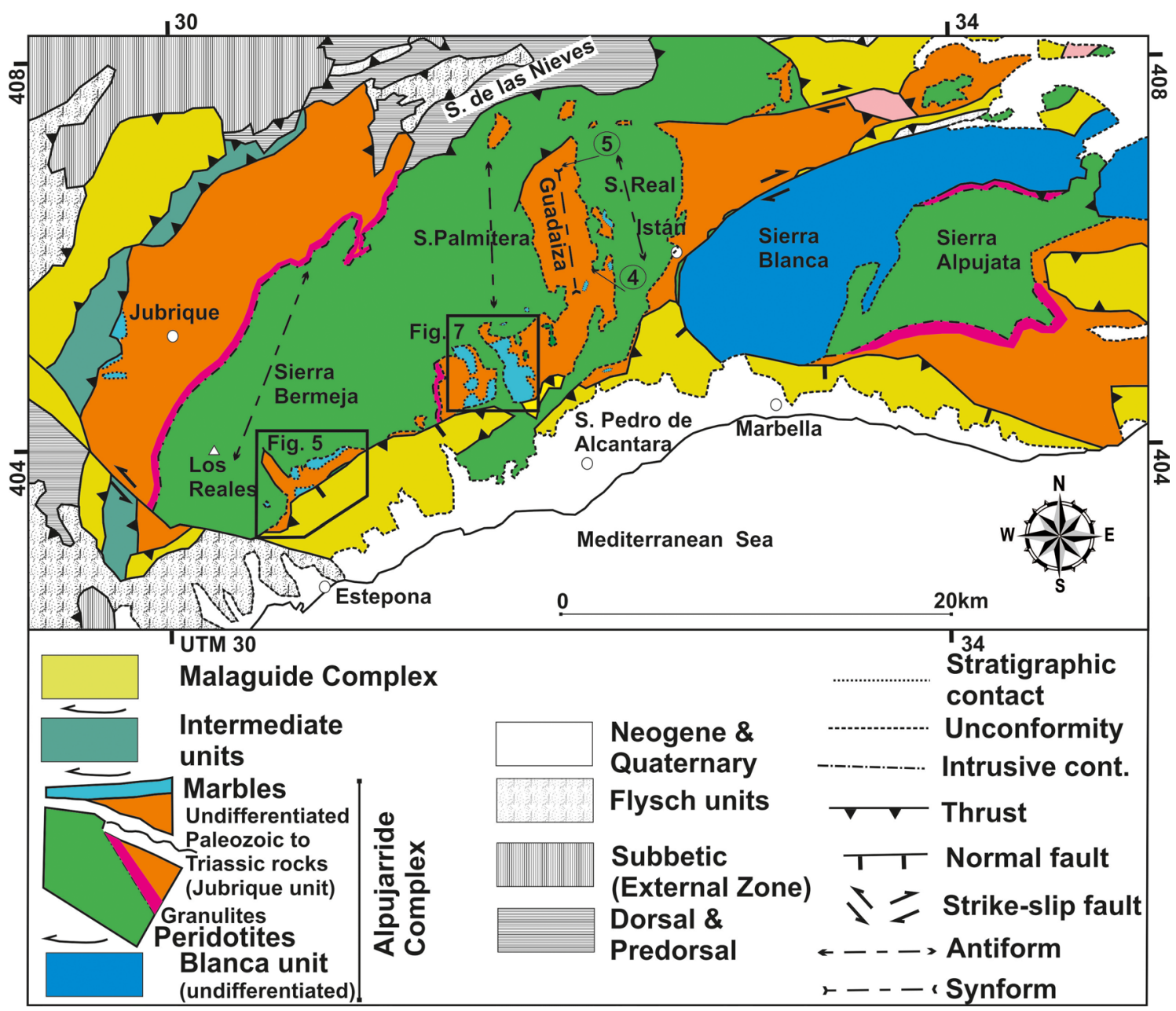

Figure 2.-Main outcrops of the Ronda Peridotites. The position of Figs. 6 and 8 is indicated by the squares as well as the position of cross-sections 4 and 5 shown in Fig. 8.

they thrust during the Alpine orogeny over crustal materials, this last corresponding to the Guadaiza unit (Lundeen, 1978; Dickey et al., 1979; Balanyá \& García-Dueñas, 1991; Tubía et al., 1993, Esteban et al., 2008, Tubía et al., 2013, among many others). Nevertheless, this overthrust cannot be deduced from the geologic map (Chamón Cobos et al., 1978; Piles Mateos et al., 1978a). This thrusting is real in other places, for instance in the northeast of Sierra Alpujata (to the east of the study area), where the peridotites locally overthrust the Blanca unit (Tubía et al., 1997) and in the Sierra de las Nieves, where the peridotites spectacularly overthrust Mesozoic rocks, in this case of the Dorsal Complex (Mazzoli \& Martín Algarra, 2011 and Mazzoli et al., 2013).

As can be seen, the age of the emplacement of the Ronda and Beni Bousera peridotites remains an open question and this article seeks to resolve this issue. For this, the presence of two unconformable formations over older, partially eroded, rocks, even over the peridotites, is crucial. The dating of this emplacement is helped by the age determined in zircons found in one layer of interbedded acidic rocks within the lower unconformable formation and by several details of the structure.

\section{Geological setting}

Both cordilleras, Betics and Rif, are formed by External and Internal zones (Fig. 1). The Betic External Zone forms part of the $\mathrm{S}$ and SE sedimentary cover of the Palaeozoic Iberian shield and occupies the northern part of the Betic Cordillera. In the Rif, the External zones cover part of the Palaeozoic 
Moroccan Meseta, and their sedimentary sequences were deposited in a basin situated to the $\mathrm{N}$ and NE of the Meseta. Between the two External zones is located the Internal Zone, common to both cordilleras.

The Internal Zone is formed by four superposed tectonic complexes, each formed in turn by different tectonic units. From bottom to top the tectonic complexes are the Nevado-Filabride (outcropping only in the Betics), the Alpujarride, which is called Sebtide in the Rif; the Malaguide (Ghomaride in the Rif); and the Dorsal. The two lower, NevadoFilabride and Alpujarride complexes are affected by the Alpine metamorphism, while the Malaguide and the Dorsal are generally not affected or weakly affected, with local exceptions. Variscan deformations and metamorphism affected with different intensity the Nevado-Filabride, the Alpujarride, and the Malaguide complexes.

The present structuring of the Internal Zone corresponds to the Alpine orogeny, in a process that was accompanied from the early Miocene, or even slightly before, by its westward drift (Durand-Delga \& Fontboté, 1980; Wildi, 1983; Sanz de Galdeano, 1990) from the central part of the western Mediterranean.

The Ronda peridotites form the bottom of the Alpujarride/Sebtide unit called Jubrique or Los Reales (in this case including the peridotites) in the Betics and Beni Bousera in the Rif (Fig. 1). To the east of Los Reales is located the Blanca or Sierra Blanca unit, Guaro, and Guadaiza (depending on the extension and the limits considered for the unit by the different authors). The Blanca (Fig. 2) unit is generally considered to be situated under the peridotites.

An aureole of garnet-rich migmatitic granulites (kinzingites) is well exposed, overlying the peridotites, in the zone of Jubrique. Migmatitic granulites evolve towards the top to migmatitic gneisses, variable-coloured schists (darker at the bottom), in their upper part attributed to the Triassic, followed by phyllites, also attributed to the Triassic, and finally by Triassic marbles (Olmo Sanz et al., 1987) (Fig. 2). The Jubrique unit is overlain, in turn, by three tectonic units with lithological and metamorphic characteristics intermediate between the Alpujarride and Malaguide complexes (Didon et al., 1973; Sanz de Galdeano et al., 2001), the Malaguide complex being situated at the top.
South and east of the Sierra Bermeja the aureole surrounding the peridotites, visible for instance in the area of Jubrique situated more to the west, is not visible with the exception of some points where it has been preserved (Fig. 2). However, an intriguing sequence has been described in this zone (Chamón Cobos et al., 1978; Piles Mateos et al., 1978a and b): the "granitoid gneisses" generally situated over the peridotites. Nevertheless, in other descriptions, the same rocks were interpreted as tectonically located below the peridotites and ascribed to the underlying Blanca unit (Lundeen, 1978) or Guadaiza unit (Tubía, 1985); Although both names are partially equivalent, here we use that of the Guadaiza unit, reserving the name of Blanca unit for the rocks directly linked with Sierra Blanca, situated more to the east (Fig. 2).

The position of these rocks, above or under the peridotites, is a crucial subject. Each proposed position involves very different interpretations not only relative to the type and origin of the rocks but also concerning the geologic evolution of the western part of the Betic- Rif Internal Zone. This subject is one of the key points of the present article.

Esteban et al. (2008, 2011) and Tubía et al. (2013) interpreted the Guadaiza unit as recording two "anatectic events", based on the assumption that this unit is tectonically thrust by the peridotites. The oldest events would originate the Istan migmatites, which has been dated as $319 \pm 8 \mathrm{Ma}$ and $299 \pm 4 \mathrm{Ma}$. They added that "by contrast, the second migmatisation event would be Alpine in age, $22 \mathrm{Ma}$ ". This second type of migmatites forms a "dynamothermal aureole". Located between the two types of rocks, they described a sequence of $\sim 150 \mathrm{~m}$ consisting of dark schists and brown quartzites. In the dynamothermal aureole, these authors included blocks of marble (see their Fig. 3). Recently, Acosta-Vigil et al. (2014) indicates a Variscan age $(\approx 280-290 \mathrm{Ma})$ for the previous dated rocks, without mention the Alpine stage. Platt et al. (2013) wrote that "the peridotites rest on a sequence of high-grade schist, marble, and granitic gneiss, with a layer several tens to $100 \mathrm{~m}$ thick of migmatitic breccia along the contact", their "Subperidotite complex", interpreted as formed by the hot overthrusting of the peridotites over the underlying Guadaiza unit.

Instead of the sequence described by Esteban et al. (2008, 2011), Tubía et al. (2013), and Platt et al. 
(A)

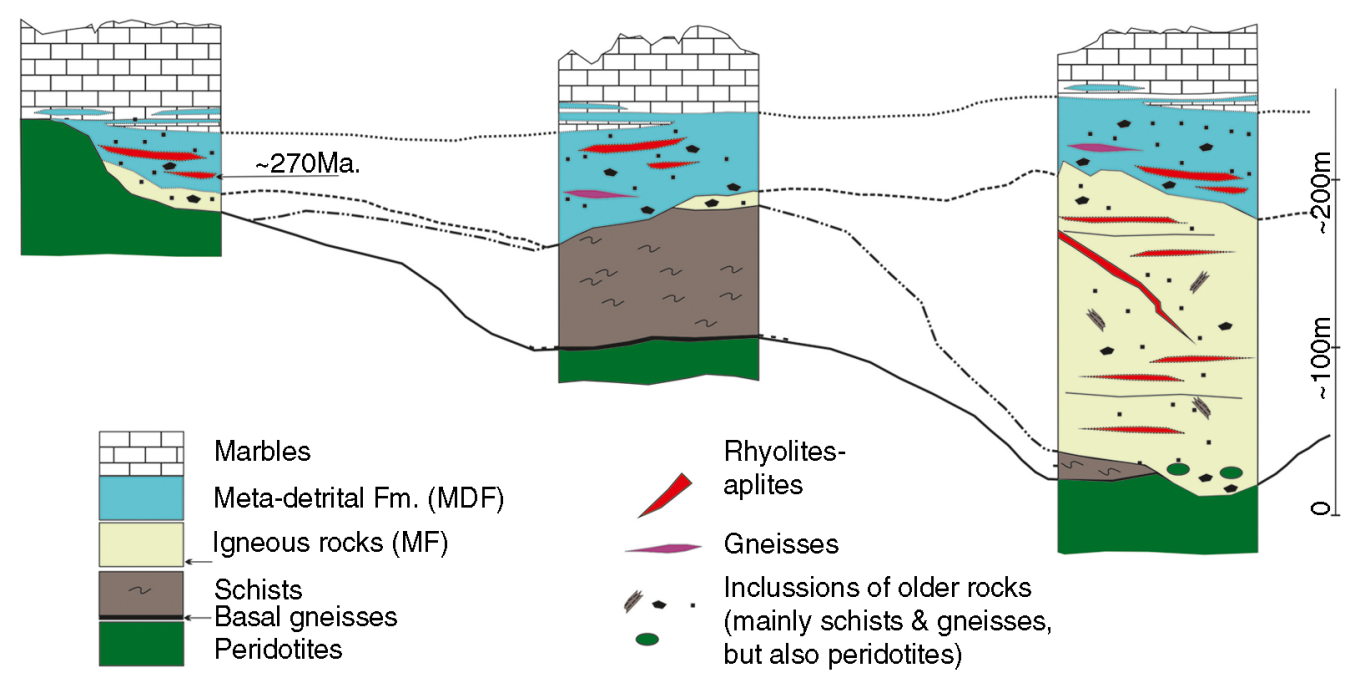

Figure 3.-Idealized lithologic sequences of the formations situated over the peridotites in the study sectors. A: Column corresponding to the N Estepona area and partially to La Zagaleta. B: Sequences to the W of Benahavis and partially to La Zagaleta and in some places of the Guadaiza Valley. C: Sequences corresponding mainly to the SW-NE border of the Guadaiza Valley.

(2013), tectonically located under the peridotites, we have found a magmatic formation and two metasedimentary formations in the same area, all located over the peridotites, in agreement with the previous description and cartography of Chamón Cobos et al. (1978) and Piles Mateos et al. (1978a and b). These formations are described as follows.

\section{The magmatic formation (MF)}

The magmatic formation (MF; Fig. 3), which strongly recalls the rocks from the Hacho unit (Ceuta, Northern Rif) and also part of the bottom of the Blanca unit, forms a succession of porphyritic granitoids and rhyolites that at many points directly overlie the peridotites. The thickness of this formation is highly variable; in the north of Estepona zone it is less than $100 \mathrm{~m}$, whereas in the Guadaiza valley it locally surpasses $200 \mathrm{~m}$. The MF lies either over the peridotites or over the schists and have a brown to grey colour, not developing schistosity or foliation but a magmatic banding is locally well preserved (Fig. 4A). The rocks contain abundant enclaves, consisting mainly of dark schists, gneisses (Fig. 4B) and altered peridotites. At the thin-section scale the rocks show variable mineralogical composition and texture. The most typical samples contain abundant pseudomorphs after cordierite, which form, with quartz and plagioclase phenocrysts and minor K-feldspar, the bulk of the rock (Fig. 4C). Magmatic red biotite is extensively chloritized and white mica is considered a late product. The presence of inclusions of altered cordietite in magmatic phases indicates a restitic or magmatic origin (Fig. 4D). Other phases such as restitic garnet, graphite, and apatite are also abundant. The rhyolitic layers contain abundant $\mathrm{K}$-feldspar, while cordierite is rare. They show no signs of metamorphic or tectonic deformations (Fig. 4A).

\section{Sedimentary formations unconformably deposited over the Ronda peridotite south and east of Sierra Bermeja}

Two sedimentary formations overlie the peridotites: The lower one is a detrital formation and the upper one is a marble formation.

\section{The meta-detrital formation (MDF)}

The MDF is situated unconformably over the MF or even over the schists and the peridotites (Fig. 3). Its thickness is variable, oscillating between 0 and $100 \mathrm{~m}$. It forms a succession of rocks, with grain size ranging from grain size ranging from rudite, to arenite, and to silt. Poorly sorted conglomerates with rounded clasts of peridotites and schists are 

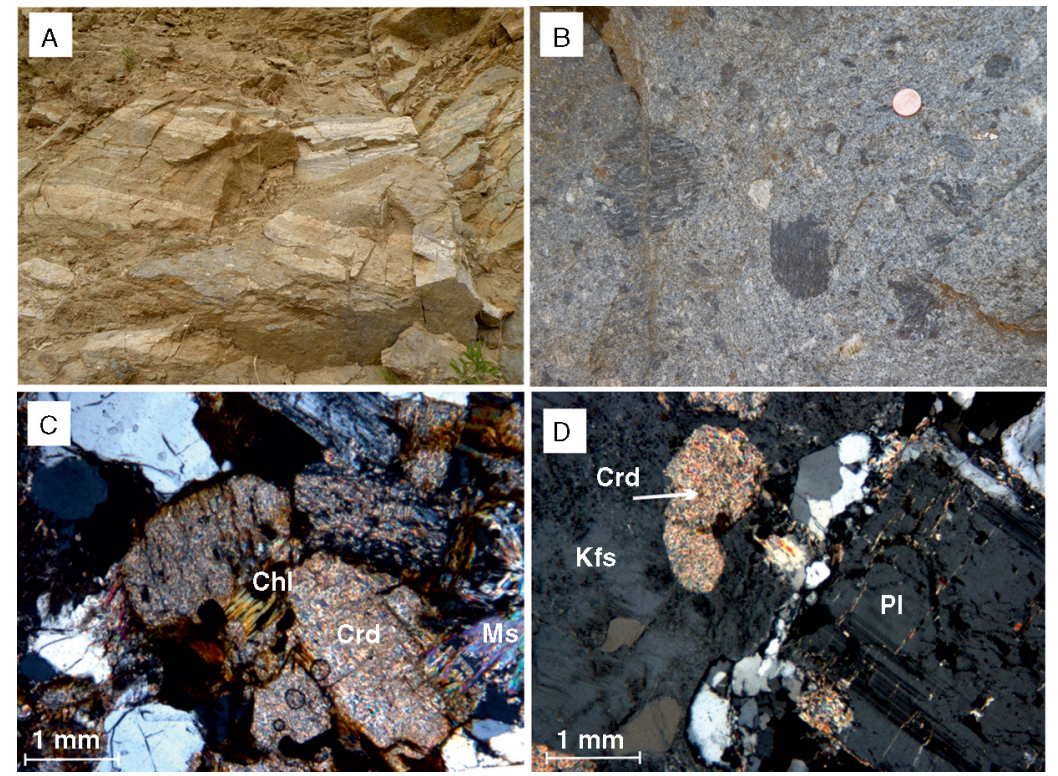

Figure 4.-Images of the MF. A: Example of not deformed magmatic banding in the MF. B: Field aspect of porphyritic magmatic rocks containing unoriented fragments of dark schist. C: Petrographic image (crossed nicols) showing high cordietite content in some magmatic rocks. D: Petrographical image (crossed nicols) showing altered cordierite included in magmatic feldspar. In this and the following figure, mineral symbols according to Whitney \& Evans (2010).
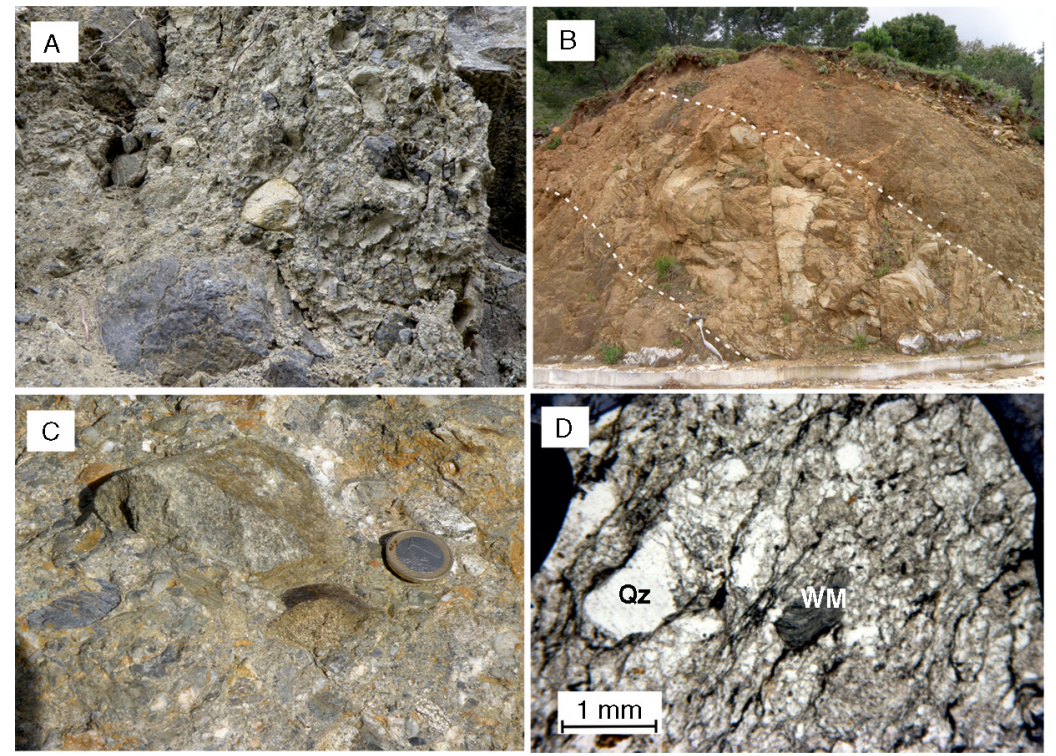

Figure 5.-Images of the MDF. A: Rounded clasts of peridotites and schists at the bottom of the MDF, directly above of the peridotites, $\mathrm{km} 42.3$ of the road from Ronda to S. Pedro de Alcantara. The photo is approximate $1 \mathrm{~m}$ wide. B: Thick level of the acidic rock used for $\mathrm{U}-\mathrm{Pb}$ geochronology, parallel to the stratification of the MDF. C: Conglomerate interbedded with quartzite in the top of the MDF, near the bottom of the marbles. Note the roundness of the clasts. Locally, some of them correspond to peridotites (SW border of Monte Mayor). D: Petrographical image (plane polarized light) of a badly selected greywacke with clasts of graphitous white mica and quartz and a finer-grained matrix-cement of quartz, white mica, and calcite.

present at the bottom of the MDF, directly over the peridotites (Fig. 5A). In well-preserved outcrops, the visible disposition corresponds to thin to medium stratification, locally interbedded with acidic rocks (Fig. 5B). The sequence also contains levels of quartzite, reaching locally $>1 \mathrm{~m}$ in thickness, with 
thinner beds towards the top. Conglomeratic levels are also found interbedded with quartzite at the top of the MDF (Fig. 5C). At the thin-section scale, the greywackes show a bad selection with clasts, graphitous white mica, plagioclase, and rock fragments, a matrix formed mainly by fine-grained quartz and small white mica flakes with a cement of calcite (Fig. 5D).

The MDF grades upwards to the marble formation. The transition from the MDF to the marbles is not uniform. Thin levels of marbles appear near the top of the MDF, which become progressively more abundant.

\section{The marbles}

The marbles (Fig. 3) lie either over the MDF in a normal stratigraphic contact, or unconformably over the MF and over older rocks, even the peridotites (Figs. 7, 8 and 9). The marbles are white, with crystal size of several millimetres, providing a saccharoidal aspect to the rock. At the bottom of the formation, the marbles include levels of finegrained detrital rocks (Fig. 6A), without apparent metamorphism. Locally, the lower levels of marbles also contain rounded pebbles, cobbles, and blocks of dark schists (Fig. 6B). At higher levels, thin meta-detrital beds present tightened small folds. These marbles conserve a maximum thickness of 150-170 $\mathrm{m}$. The top has been eroded.

Although the surface of discordance between marbles and peridotites is usually covered by soils and vegetation, the general geometry of the contact is unambiguous. Moreover, in the area of Benahavis, particularly in the Zagaleta housing estate, it is possible to see the unconformity at several points, particularly in a new cut in the slope of a hill (UTM coordinates: longitude 317900/latitude 404635, 1950 European Datum), (Fig. 6C). Despite that the contact between marbles and peridotites is locally affected by faults, even by reverse faults locally thrusting the peridotites
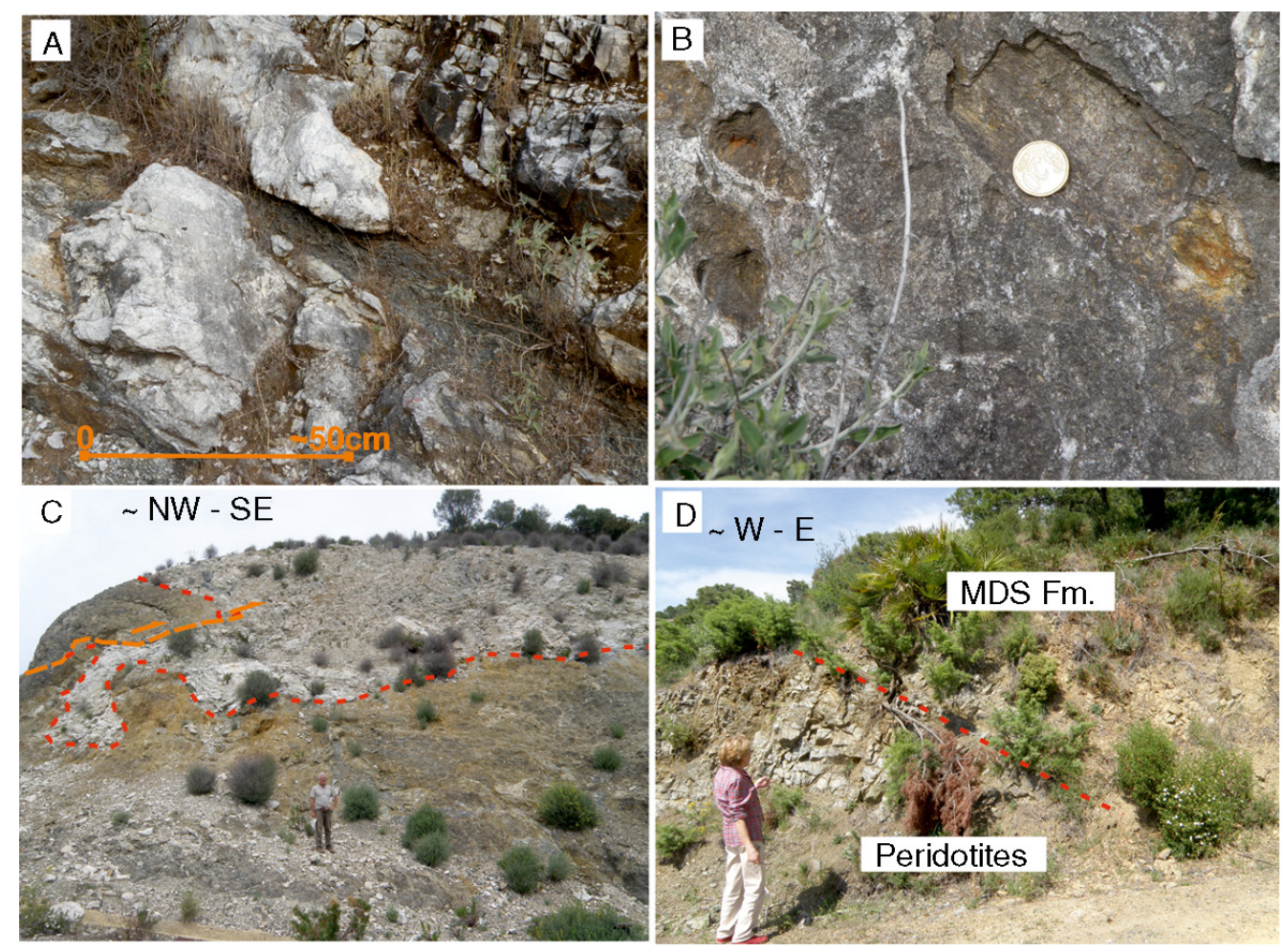

Figure 6.- Images of the marbles and the peridotites in the Guadaiza area. A: Thin levels of the MDF interbedded with marbles near their bottom. B: Clasts of dark schists in the lower levels of the marbles ( $\mathrm{N}$ of Monte Mayor). C: Unconformity between peridotites (at the bottom) and marbles (at the top). The contact is locally occupied by an old weathering profile (La Zagaleta area). A local reverse fault repeating the peridotite over the marbles is visible on the left, also with marbles at the top. Red lines mark the unconformity; the orange line marks the reverse fault. D: Unconformity of the MDF (red line) above the peridotites in middle of the Guadaiza valley (UTM coordinates: longitude 321675/latitude 4046325. 1950 European Datum). 
over the marbles, the general geometry shows that the peridotites underlie the MF and the MDS or are even directly underlie the marbles.

\section{Structure of the area}

The structure of the study area is simple in general, and for its description we have divided the area into three sectors.

\section{The N Estepona sector}

To the NW of Estepona the position of the contact between the peridotites and MF and MDF formations is controversial. In these points there are two faults (Fig. 7). That situated to the East presents its scarp sinking the two cited formations in relation to the peridotites. But the other fault has no clear outcrops and could be interpreted as a very inclined thrusting of the peridotites over the mentioned formations. Eastwards, the contact between the unconformable formations and the peridotites is clear: the MF, MDF, and the marbles are situated over the peridotites and dip to the south from 70 to $10-20^{\circ}$, with values of $30-40^{\circ}$ being predominant. Moreover, the reliefs indicate clearly the relative position of these rocks, maintaining the peridotites in the lower position (see cross-section 1 in Fig. 9).

\section{The Benahavis sector (Fig. 8 and cross-sections 2 and 3 in Fig. 9)}

The structure is more complex in this sector owing to the presence of some tectonic contacts, including normal, vertical (with not know regime, dip-slip or strike-slip), and reverse faults, the latter causing local thrusting of peridotites. However, the disposition of the MF, the MDF, and the marbles

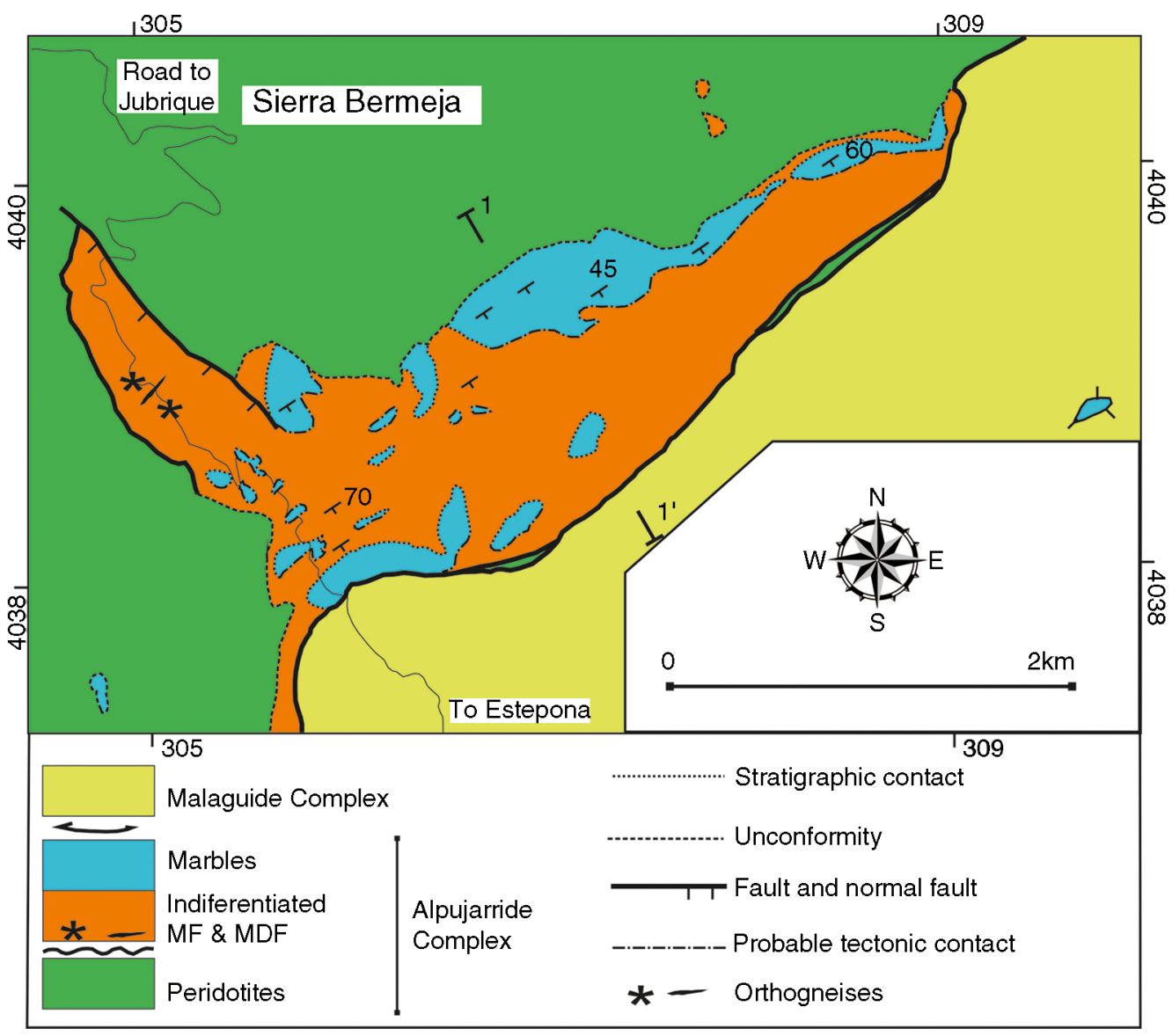

Figure 7.-Geologic simplified map (originally made over a topographic 1:25000 scale map) of the southern border of the Ronda Peridotites the north of Estepona. Its position is marked in Fig. 2. The thin black line is the road from Estepona to the top of Sierra Bermeja and Jubrique. 


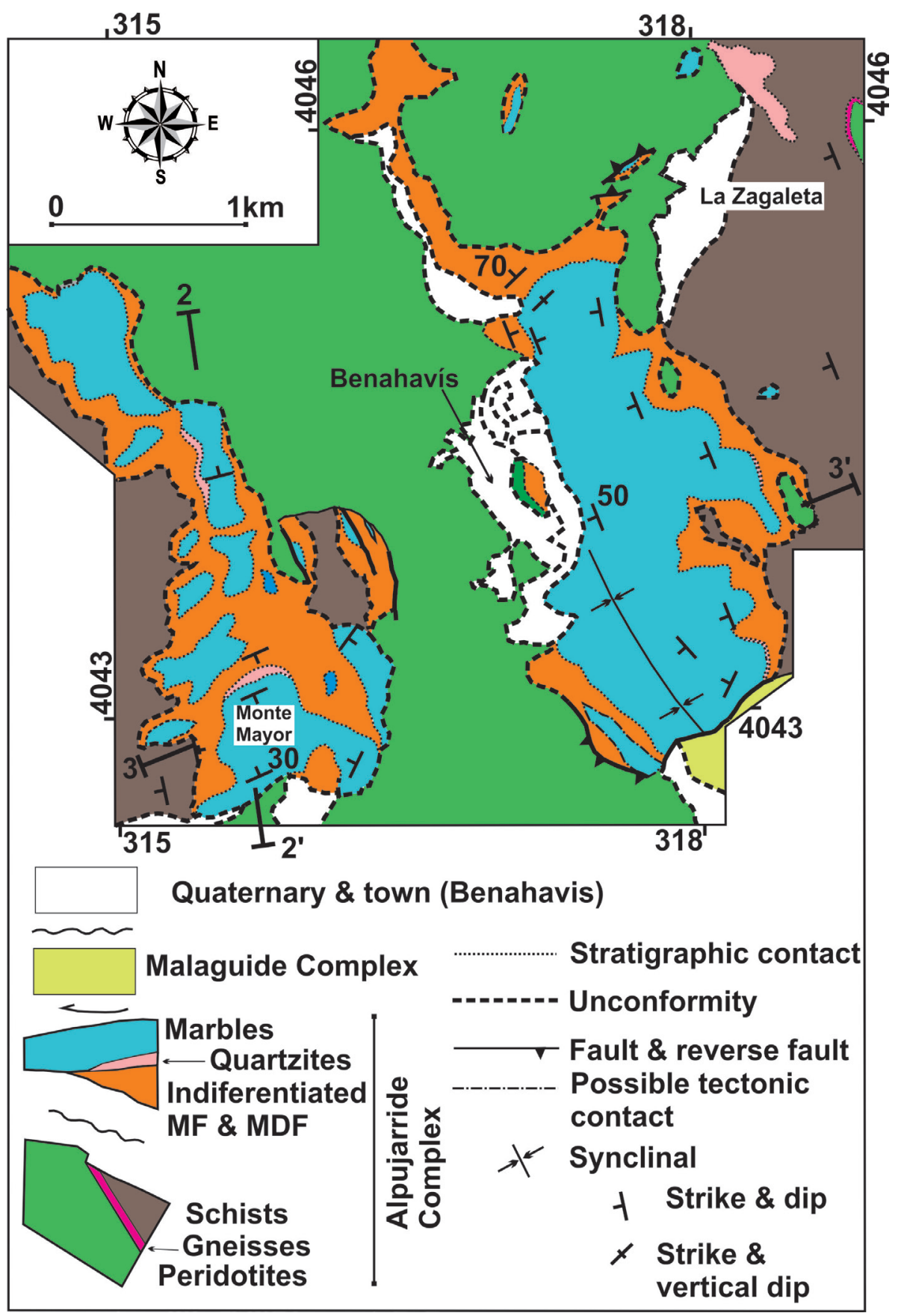

Figure 8.-Geological simplified map (originally made over a topographic 1:25000 scale map) of the area of Benahavis-La Zagaleta. Its position is marked in Fig. 2.

above the peridotites is also evident in this area. This evidence is obtained by the fact that the MF, the MDF and the marbles are generally situated in the higher parts of the reliefs, and the peridotites occupy the valley, moreover that the contact are clear in several points.
There are also folds oriented NNW-SSE, particularly the syncline formed in the marbles to the SSE of Benahavis. This fold has a reverse fault verging to the east on its south-west border, disappearing to the north, where the MDF rests directly over the peridotites. The axes of these folds plunge to 


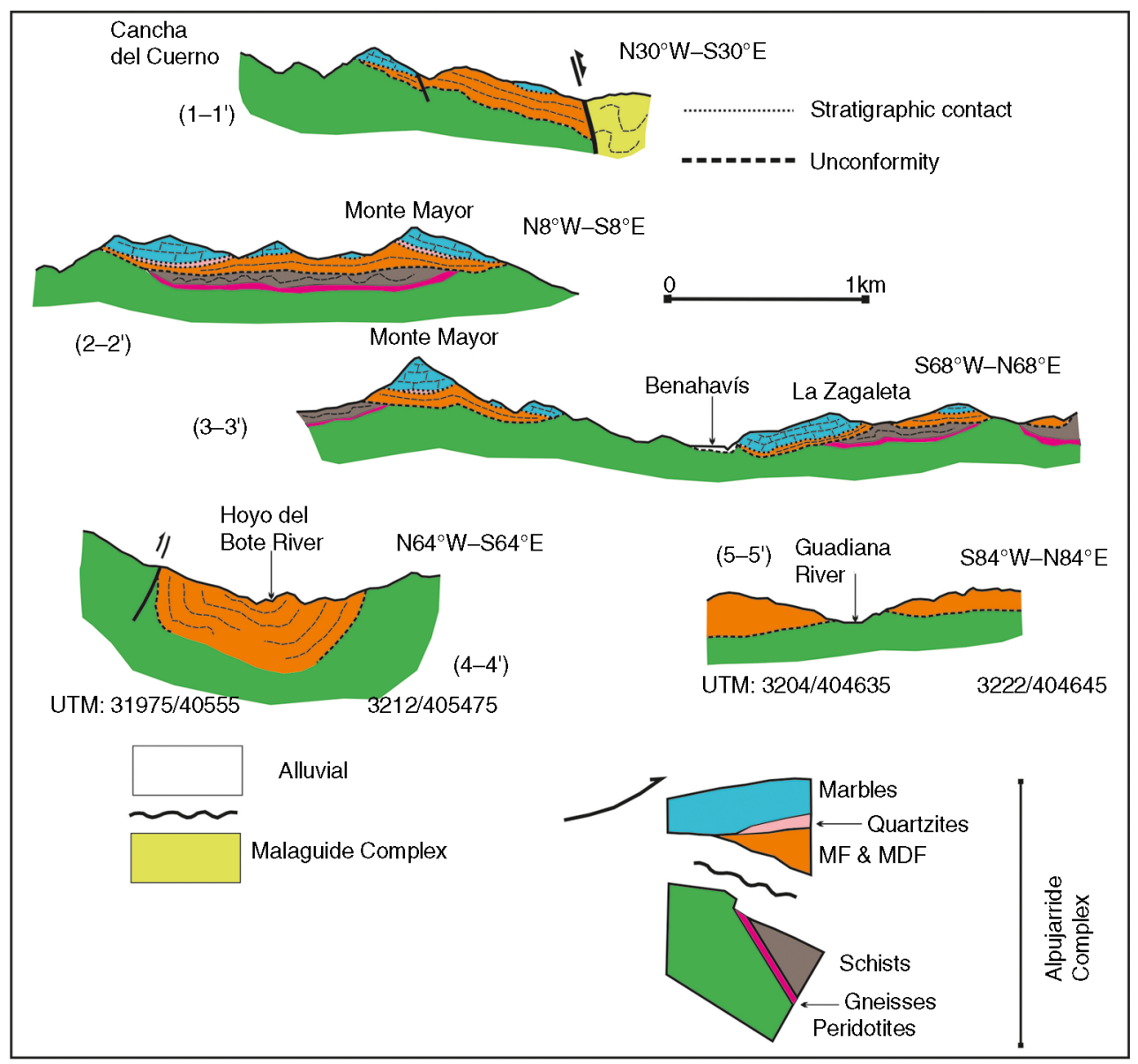

Figure 9.-Geologic cross-sections of the sectors studied. Their position is marked in Figs. 2, 6, and 7.

the south, as happens in general with the rest of structures.

As a whole, the Benahavis sector constitutes only the SW end of the Guadaiza valley, described below.

\section{The Guadaiza sector}

This sector is larger than the previous ones and we do not include a new cartography. The description, shown in Figs. 8 and 9, are based on field observations. The general disposition of the MF, the MDF, and the marbles with respect to the schists and the peridotites is similar to that of the previous sectors, these formations being located above the dark schists and peridotites.

Locally the peridotites thrust the MF, as in the NW part of the area (Fig. 2). There the contact is nearly vertical (Fig. 9, cross-section 4) and locally the thrust is visible. However, on the NE border the contact dips approximately $70^{\circ}$ to the west with the bedding of the MF and the MDS marking their position above the peridotites. On the contrary, in other places (Fig. 6D and Fig. 9, cross-section 5), the contact of the MF and the MDS with the peridotites has gentle dip, the peridotites being in the lower position.

\section{Regional tectonic aspects}

Sierra Bermeja is a NNE-SSW antiform while the sectors to the $\mathrm{N}$ of Estepona and Benahavis are situated in synforms (Fig. 2). Sierra Palmitera, directly to the east of Benahavis, also forms an antiform. More to the east, the Guadaiza valley is a synform, although previous interpretations (with the exception of Piles et al. 1978a) indicate that the rocks of this valley are thrust by the peridotites, thus defining the Guadaiza unit. Immediately to the east lies the mountain of Sierra Real, another antiform, and the Istan valley corresponding partially to a synform. 
In addition to the sectors described, dispersed outcrops of MF, MDF, and marbles situated above the peridotites are widespread in the zone (Fig. 2).

\section{$\mathrm{U}-\mathrm{Pb}$ geochronology of zircon from the acidic rocks}

The sample used for U-Pb SHRIMP zircon geochronology was taken in one of the thickest levels $(2-3 \mathrm{~m})$ of acidic rocks situated $\mathrm{N}$ of Estepona in the MDF (Fig. 5B). This sample has $68 \mathrm{wt} . \% \mathrm{SiO}_{2}$ and is very rich in $\mathrm{K}_{2} \mathrm{O}(6.6 \mathrm{wt} \%$ ) with respect to $\mathrm{Na}_{2} \mathrm{O}$ (1.6 wt.\%). The sample is peraluminous, with molar $\mathrm{Al}_{2} \mathrm{O}_{3} /\left(\mathrm{CaO}+\mathrm{Na}_{2} \mathrm{O}+\mathrm{K}_{2} \mathrm{O}\right)(\mathrm{A} / \mathrm{NCK})=1.7$. The marked peraluminous composition, the high $\mathrm{SiO}_{2}$ content, and the low concentration of $\mathrm{CaO}$ and ferromagnesian elements are compatible with a melt derived from meta-sedimentary sources.

The rock has a porphyritic texture with unoriented and variably-sized K-feldspar megacrysts. In addition to K-feldspar $(\sim 30 \%)$, the rock contains quartz $(\sim 22 \%)$, plagioclase $(\sim 14 \%)$, white mica $(\sim 16 \%)$, biotite (13 wt.\%), and chlorite (4\%). Accessory phases are apatite, graphite, rutile, zircon, sillimanite, spinel (hercynite), and ilmenite. At the thin-section scale, subhedral to anhedral $\mathrm{K}$-feldspar $\left(\mathrm{Or}_{80} \mathrm{Ab}_{20}\right)$ and plagioclase $\left(\mathrm{Ab}_{62-67}\right)$ appear surrounded by interstitial quartz and mica. Roundish or lobate quartz grains also occur in $\mathrm{K}$-feldspar and plagioclase grain interiors. White mica appears in three main textural domains: a) In rounded, apatite-bearing millimetre-sized microdomains, in which it forms thin intergrowths with biotite, similar to those described in the Torrox gneisses (García-Casco et al. 1993; Ruiz Cruz \& Sanz de Galdeano 2009); b) as late large flakes; and c) as minute flakes (sericite), a product of the alteration of plagioclase grains.

Zircon was separated using panning, first in water and then in ethanol, and magnetic techniques followed by handpicking of the concentrates using a binocular microscope. Once mounted and polished, zircon grains were studied by optical microscopy and cathodoluminiscence (CL) imaging and analysed for U-Pb using a SHRIMP IIe/mc ion microprobe at the IBERSIMS laboratory of the University of Granada (Spain). The SHRIMP analytical method is described in www.ugr.es/ ibersims. The uranium concentration was calibrated using the SL13 reference zircon (U: $238 \mathrm{ppm}$ ). U:Pb ratios were calibrated using the TEMORA-1 reference zircon (417 Ma, Black et al. 2003), which was measured every 4 unknowns. Point-to-point errors (95\% confidence interval) on the age standard were $\pm 0.23 \%$ for ${ }^{206} \mathrm{~Pb} /{ }^{238} \mathrm{U}$ and $\pm 0.46 \%$ for ${ }^{207} \mathrm{~Pb} /{ }^{206} \mathrm{~Pb}$. Data reduction was undertaken with the SHRIMPTOOLS software (downloadable from www.ugr.es/ fbea) using the STATATM programming language.

Zircons are usually within the range of 100-200 $\mu \mathrm{m}$ in length, subhedral to euhedral prisms. Table 1 summarizes the $\mathrm{U}-\mathrm{Th}-\mathrm{Pb}$ analytical data and the ages derived. Thirty crystals were studied, resulting in a total of 40 individual analyses. Analytical work was guided by CL images of all mounted crystals and new CL and BSE images were made after analysis in order to establish the precise location of the shot points.

Figure 10 presents the isotopic data in the Weherill ${ }^{206} \mathrm{~Pb} /{ }^{238} \mathrm{U}$ vs. ${ }^{207} \mathrm{~Pb} /{ }^{235} \mathrm{U}$ concordia diagrams. Along the concordia, scattered ages of $\sim 2000, \sim 1000$, $\sim 600$, and $430-550 \mathrm{Ma}$ and one main cluster of ages between 235 and $310 \mathrm{Ma}$ (Fig. 10A), with a maximum at $270 \mathrm{Ma}$, may be recognized (Fig. 10B and C). Ages $>450 \mathrm{Ma}$ correspond to detrital early Proterozoic, Grenvillian, Pan-African, and Caledonian cores (Figs. 11A-A' and B-B'). Variscan cores with ages between 300 and 320 Ma show either oscillatory zoned structures, which are recognized as typical of magmatic crystallization, and signs of fracturing (Fig. 11C') or textures reflecting advanced later alteration (Fig. 11D'). These cores are interpreted as corresponding to primary source rocks, and trained with the melt. Variscan cores with ages $<280 \mathrm{Ma}$ (Fig. 11E-E') and rims with ages $\sim 270 \mathrm{Ma}$ and clear oscillatory zoning (Figs. 11A', B' and C') are interpreted as reflecting the age of the magmatic rock. Rims providing mixed Variscan-Alpine ages show an obscured oscillatory zoning, suggesting alteration during the Alpine event (Fig. 11D'). Well-defined Alpine rims have not been identified in the study sample.

\section{Metamorphic evolution deduced from the MF}

As a whole, most phases in the MF, including altered cordierite, are considered magmatic in origin. Exceptions are apatite, garnet, and kyanite, which are considered to be trained by the melt from the feeder rock and zircon, which has a mixed 


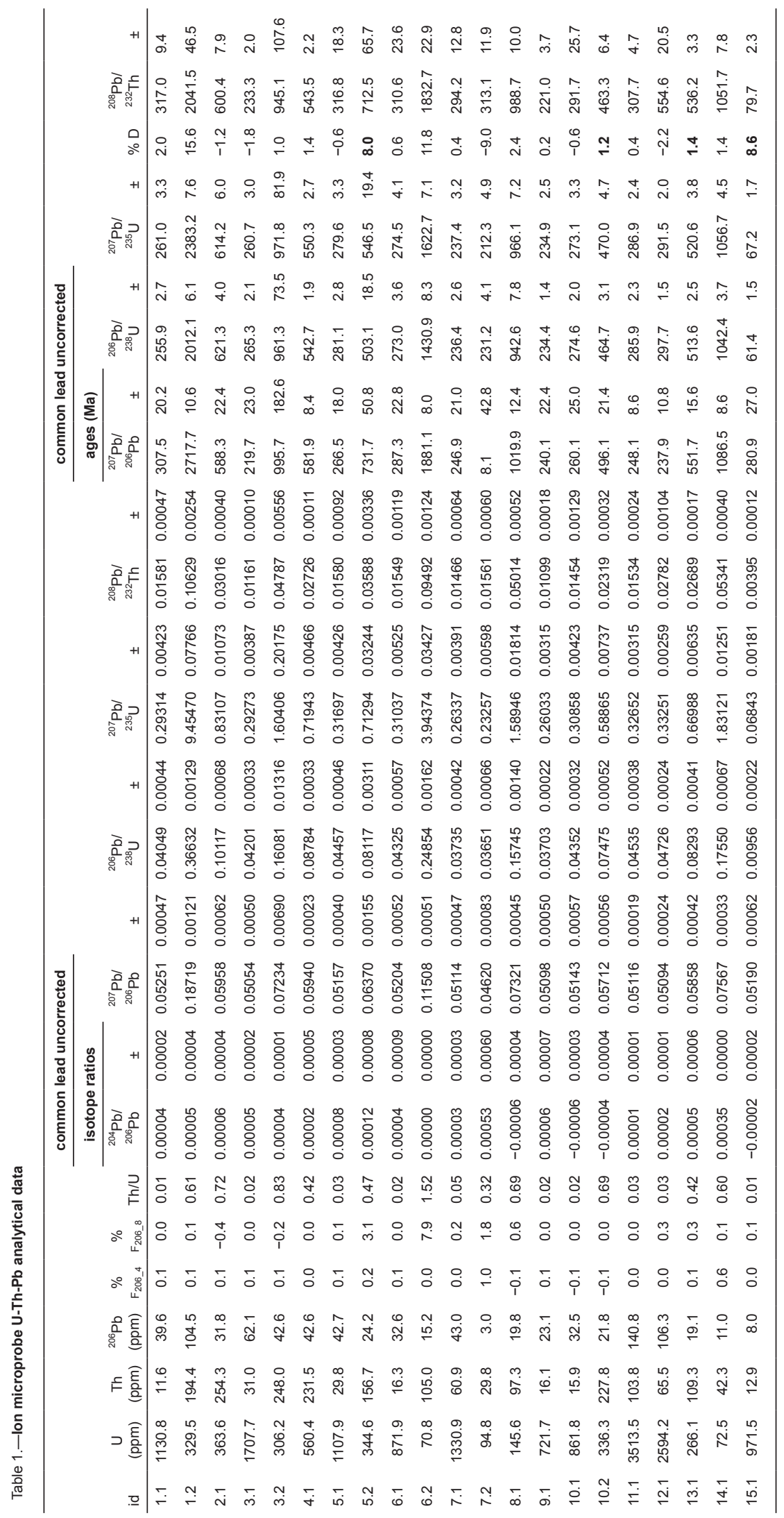




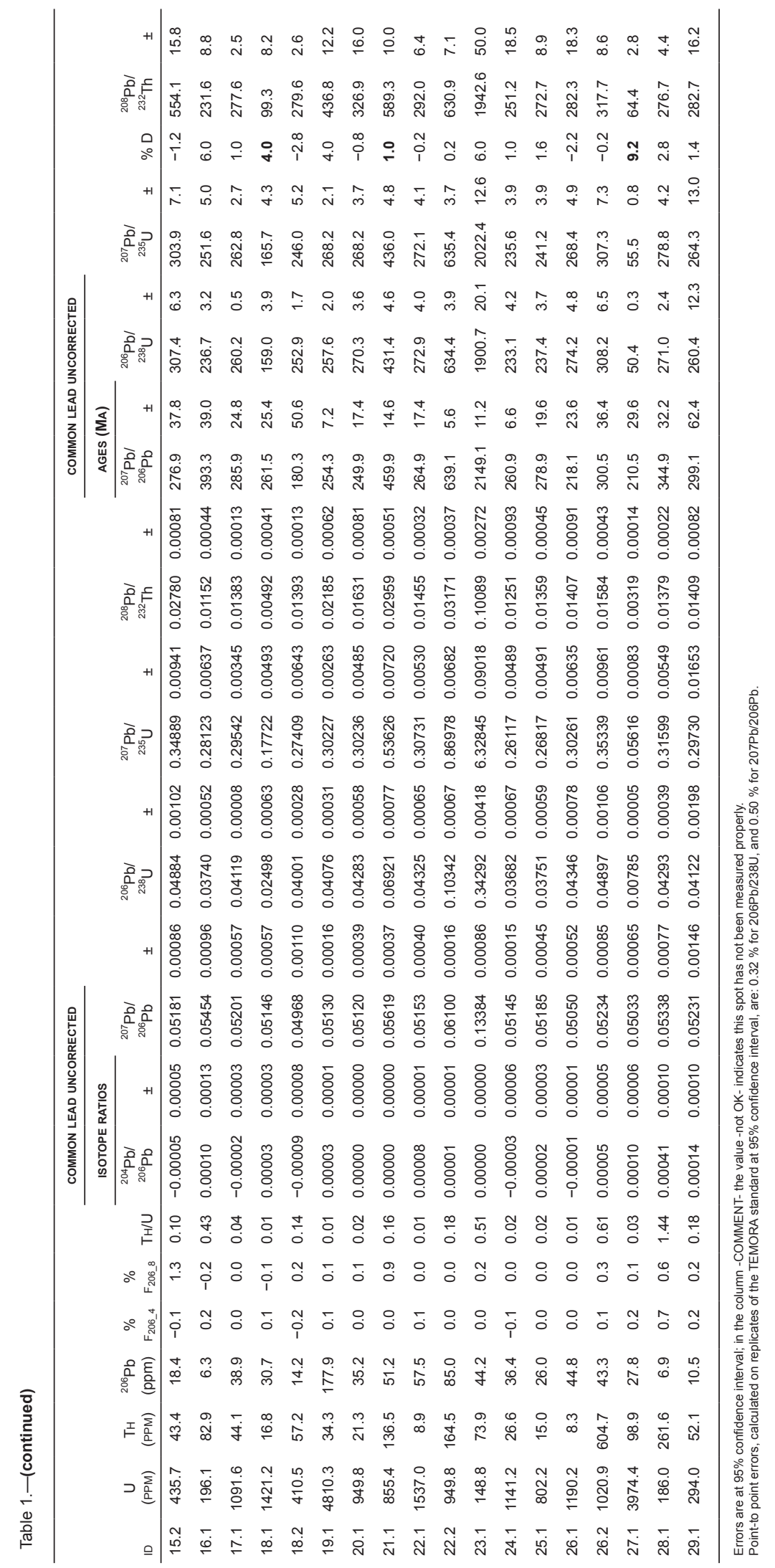



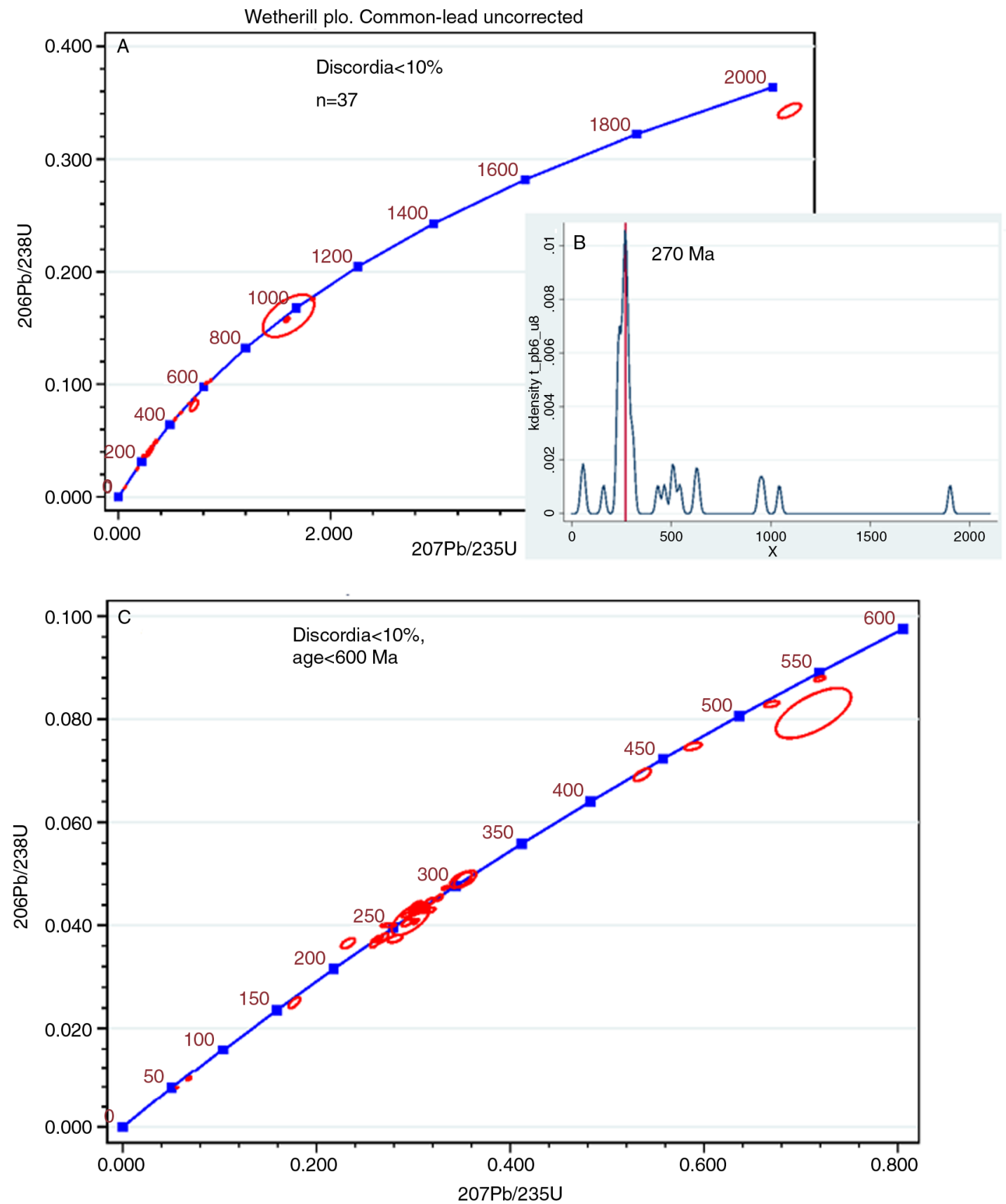

Figure 10.-Wetherill concordia plots of the SHRIMP data for the complete age range (A and $B)$ and for ages $<600$ Ma $(C)$. Error ellipses were calculated at $95 \%$ confidence.

origin. Pseudosections constructed with Perple_X (Connolly 2009) (not shown) reveal that, despite the wide compositional field of biotite, its composition $\left(\mathrm{X}_{\mathrm{Mg}}<0.32\right)$ is restricted to low-P/high-T conditions $\left(0.2-0.4 \mathrm{GPa} / 800-900{ }^{\circ} \mathrm{C}\right)$, suggesting a magmatic origin. Cooling could have been responsible for the sillimanite+hercynite formation. White mica is not stable under these conditions.

The Alpine metamorphism is recorded, in appearance, by white mica and chlorite (e.g. Fig. 4C). These data are insufficient to estimate the Alpine metamorphic grade. Both the lack of primary 

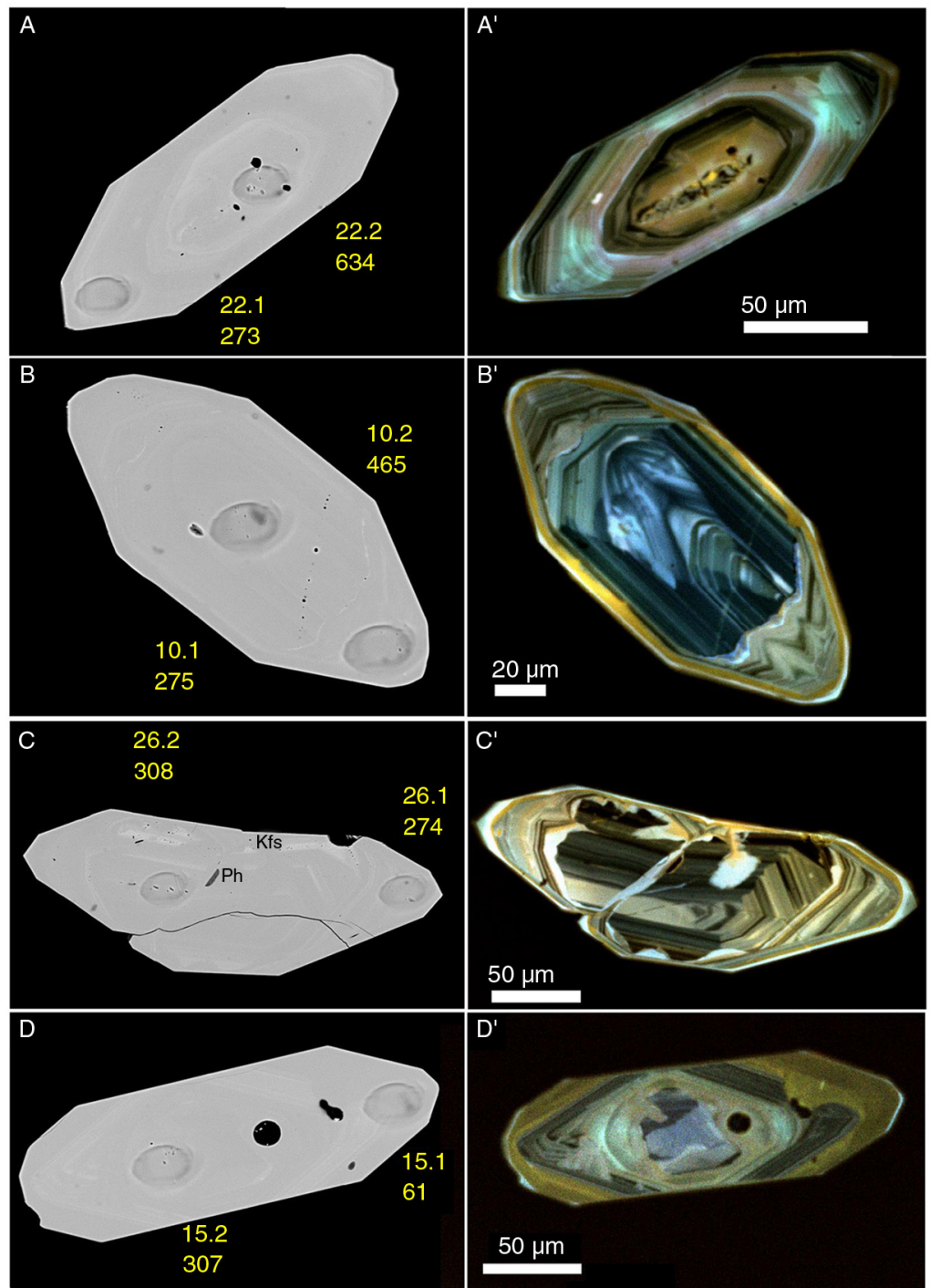

$50 \mu \mathrm{m}$
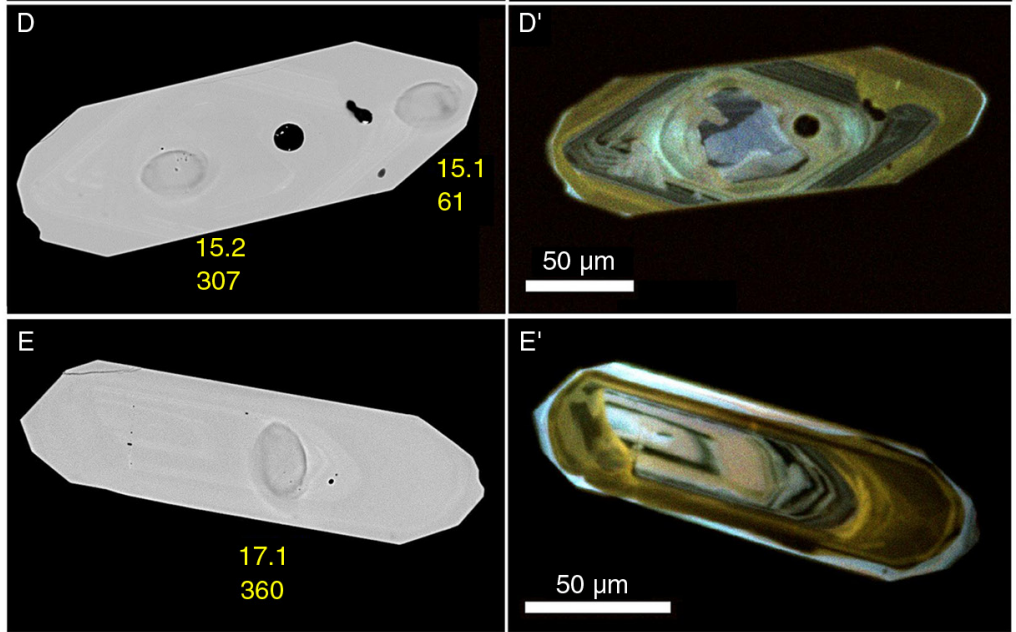

Figure 11.-BSE and CL images of selected zircon grains. See text for explanation.

garnet and the presence of white mica restrict the metamorphic field to a wide range of increasing $\mathrm{P}-\mathrm{T}$ conditions and the location of the $\mathrm{Si}$ isopleths restricts the possible metamorphic field to a narrower P-T field between $500{ }^{\circ} \mathrm{C} / 0.2 \mathrm{GPa}$ and $790{ }^{\circ} \mathrm{C} / 0.8 \mathrm{GPa}$.

\section{Discussion}

The issues presented above will be treated as follows: a) a comparison of the MF with the rocks of the Hacho de Ceuta Unit; b) the meaning of the MDF and the significance of the age of the acidic 
rock; c) the age and the position of the marbles and the relations of these last two formations with the underlying rocks; and d) the significance of the structure in the three study sectors, as compared with the previous interpretations. On the basis of these data, a model is presented concerning the emplacement and times of exhumation of the peridotites in this region.

\section{Comparison of the MF with the rocks of the Hacho de Ceuta unit}

The MF occupies part of the outcrops attributed to granitoid levels (Chamón Cobos et al., 1978; Piles Mateos et al., 1978a and b) and part of the migmatites and mylonites of Esteban et al. (2008), Tubía et al. (2013) forming the Subperidotite complex of Platt et al. (2013).

The rocks show clear magmatic textures which strongly recall the rocks of the Hacho de Ceuta unit (the position of Ceuta is visible in Fig. 1). In this later unit, porphyritic rocks containing enclaves similar to those present in the MF (e.g. Fig. 4A and B) are abundant (e.g. Ruiz Cruz \& Bentabol, 2014, Fig. 2C and D). However, the MF rocks show special similarities with rhyolites from the Hacho unit, which are rich in altered cordierite (e.g. Ruiz Cruz \& Bentabol, 2014, Fig. 3A). The Hacho unit was previously interpreted as recording low-pressure/high-temperature metamorphic conditions (Kornprobst, 1962), probably on the basis of the assumed metamorphic origin of cordierite. Our estimates provided a narrow range of temperatures (between 473 and $490{ }^{\circ} \mathrm{C}$ ) for pressures between 3 and 5 kbar (Ruiz Cruz \& Sanz de Galdeano, 2012), near the lower values estimated in the MF described here.

\section{Interpretation of the MDF}

In the study area the MDF had not been previously described with the exception of Tubía et al. (1997) who described a metapelitic sequence southeast of Sierra Blanca, associated, as in the study are, to the marbles. The MDF occupies a part of the outcrops attributed to the granitoid gneisses or to the migmatites and mylonites (depending on the interpretations).

Although the vegetation and soils generally do not permit a clear separation of this formation from the MF, in our interpretation, its sedimentary origin is unambiguously demonstrated by its disposition in strata and the textures, the presence of abundant clasts of older rocks, which do not show a tectonic but a sedimentary orientation, the presence of levels of carbonates interbedded with the detrital rocks at the top of the formation and of levels of fine-grained detrital rocks intercalated within the marbles, and its position above the peridotites. There are also levels of quartzite, particularly towards the top of the formation.

Also the existence of sheet-like acidic rocks intercalated in the MDF with variable thickness, from centimetres to several metres, prevents any tectonic interpretation of the MDF. The resulting $270 \mathrm{Ma}$ age indicates a minimum Permian age for the host MDF. This stage of late to post-Variscan extension and the coupled magmatism is also common in Permian formations from the Nevado-Filabride Complex (e.g. Nieto et al., 2000; Gómez-Pugnaire et al., 2012).

\section{The marble formation}

The marbles have been previously attributed to the Precambrian-Palaeozoic (Piles et al., 1978; Chamón Cobos et al., 1978). Nevertheless, we do not know the criteria that led to this attribution, because the Alpujarride Complex contains no marbles until the Triassic, perhaps beginning at the end of the Permian. This happens, for instance, in the sequences of the Jubrique unit, on the western border of the Sierra Bermeja antiform, where the marbles appear only at the top (Fig. 2). There is no mention of Palaeozoic or older marbles in other Alpujarride sectors, with the exception of ones situated much more to the E (Aldaya, 1981), but they are in fact Triassic marbles tectonically included in the bottom, or near this bottom, of thrusting units dragged from the lower unit (Sanz de Galdeano \& López-Garrido, 2014). Palaeozoic carbonates from the Malaguide Complex (calizas alabeadas) are quite different. In addition, Devonian limestones from the Nevado-Filabride Complex are also different from the marbles of Benahavis. In this same complex, there are also Permian marbles having interbedded volcanic rocks (Gómez-Pugnaire et al., 2012), with mean ages of $282 \pm 5 \mathrm{Ma}$, in addition to Triassic marbles. According to these data, 
the attribution to the Precambrian-Palaeozoic of the marbles of the Benahavis area does not seem justified.

On the contrary, the presence of quartzites in the bottom of the marbles in the study area and the progressive passage from detrital sediments to marbles is characteristic of many Triassic Alpujarride sequences. For these reasons, our suggestion is that they should be considered of Triassic age.

As a whole, the MDF and marble protoliths were deposited over exposed and eroded rocks on an irregular surface. The carbonates represent the beginning of the marine transgression common in the Internal Zone, which later continued in the Betic External Zone.

\section{Discussion of the structure in the different sectors}

The existence to the NW of Estepona of a fault that could be interpreted as a thrusting of the peridotites over the MF and MDF formation (see the chapter of the structure of the area; the N Estepona sector) has been used to demonstrate the "general" thrusting of the peridotites. For this reason, it is necessary to move to the East, in order to see better the general geometry of the sector. There, the structure of the $\mathrm{N}$ of Estepona presents no difficulties, and previous articles indicate that the MF (or granitoids gneisses of Chamón Cobos et al., 1978), the MDF, and the marbles overlie the peridotites. This also agrees with the interpretation of Balanyá \& García-Dueñas (1991), who consider these rocks to form part of the Jubrique unit, the elements of which are situated above the peridotites. For this reason, even accepting the interpretation of a thrusting in the fault situated to the NW of Estepona, this thrust would be a local reversed fault, with only local significance.

The general structure of the Benahavis-La Zagaleta sector has the same disposition, with the MF, the MDF, and the marbles unconformably located above schists and peridotites. This interpretation agrees with that of Balanyá \& García-Dueñas (1991), who interpreted that the area comprise from Estepona to Benahavís belongs to the Jubrique unit, while the central and eastern areas would form part of the Guadaiza unit, something not demonstrable, and introduced -in our opinion- to maintain the existence of the Guadaiza unit. Other authors, such as Tubía (1985; Tubía et al., 2013), consider the entire Benahavis-La Zagaleta sector to form part of the lower Guadaiza unit.

In our opinion this sector of Benahavis-La Zagaleta is in complete continuity with that of the $\mathrm{N}$ of Estepona (to the W), and that of the Guadaiza (to the E), with the peridotites and the dark schists under the MF, the MDF and the marbles.

With the exception of Piles et al.(1978a), the articles consulted consider that the crustal rocks occupying the Guadaiza valley are overthrust by the peridotites and constitute the Guadaiza unit. Nevertheless, this is not the case and this area cannot be considered to form part of a distinct tectonically lower unit. On the contrary, our data indicate that it is part of the rocks forming in this area of a Permian-Triassic cover of the Jubrique unit (situated above the peridotites and the dark schists and formed by the MF, the MDF and the marbles). This position above the peridotites is also corroborated by the presence of dispersed and isolated outcrops of the MF, MDF, and the marbles situated above the peridotites, as in the Istán valley and at other points (see Fig. 2, to the $\mathrm{N}$ of the Guadaiza Valley). The appearance of all these outcrops indicates that the peridotites were exposed on the surface during the Permian in a wide area. On the contrary, one important consequence of the assumption of the existence of the Guadaiza unit would be the interpretation of the first exhumation of the peridotites during the end of the Oligocene- beginning of the Miocene.

Another aspect concerning the structure is the formation of the near N-S antiforms and synforms. They can be explained by the westward drifting undergone by the Internal Zone during the end of the Oligocene -early Miocene and even middle Miocene (Sanz de Galdeano, 1990). In this movement the Internal Zone collided with the External zones, forming the cited antiforms and synforms. Therefore, these latter structures are clearly related to the Alpine deformations. This was also the time when the Jubrique unit, with the peridotites at its bottom, thrust the Sierra de las Nieves, as indicated by Mazzoli and Martín Algarra (2011) and Mazzoli et al. (2013). This thrust can be seen in the northern part of the Fig. 2.

The corollary of the discussion is that the proposed thrust of the peridotites over the Guadaiza, Benahavis and $\mathrm{N}$ of Estepona lithological sequences 
does not exist, in our opinion, and consequently the interpretation of the origin of these rocks linked to this thrust has no fundament. Otherwise, the position of unconformably formations (Permian and Triassic) above the peridotites indicates the emplacement of the Ronda Peridotites during the Palaeozoic.

\section{A model of geologic evolution of the area from the Palaeozoic}

The time of the beginning of the geologic evolution of this area is not clear. The study and dating of zircon from a graphitous schist of Alpujarride units located in the central zone of the Betic cordillera led Zeck \& Whitehouse (2002) to estimate a maximum age for the deposition of the parent material of around of $500 \mathrm{Ma}$, the age of the youngest well-defined detrital zircon grains. Nevertheless, our data indicate that zircons with ages $>450 \mathrm{Ma}$ (a well-defined Caledonian population found in several localities, e.g. in the Jubrique migmatites, Ruiz Cruz \& Sanz de Galdeano, 2014), were detrital components in the feeder rocks of the granitic melt, thus constraining the age of the sedimentary protolith to $<450 \mathrm{Ma}$. Zircon domains with ages between 320 and $300 \mathrm{Ma}$ are interpreted as recording a Carboniferous melting stage in the source rock and having being trained by the melt, whereas the age of magmatic crystallization is $269 \pm 9 \mathrm{Ma}$.

Before this last age, the continental crust underwent a process of subduction. This is demonstrated by the presence of relict UH $P$ phases (mainly diamond and coesite) as inclusions in several phases (garnet, apatite and zircon) from the deepest crustal rocks (migmatitic granulites and gneisses) of Jubrique unit (Ruiz Cruz \& Sanz de Galdeano, 2014) and from the Sarchal area in Ceuta the (Rif Cordillera) (Ruiz Cruz et al., 2011; Ruiz Cruz \& Sanz de Galdeano, 2013). The age of this subduction event is uncertain, although our most recent data (e.g. Ruiz Cruz \& Sanz de Galdeano, 2014) suggest the interval 420-350 Ma. In this discussion it necessary to remember that Kornprobst (1976) cited peridotite remains and deep crustal rocks in Silurian to Carboniferous Ghomaride (Malaguide) sediments.

Despite the age uncertainties, the association of high-pressure felsic rocks and garnet peridotite is common in the European Variscan Belt - e.g. German, Austrian, Polish, and Czech parts of the Bohemian Massif; Black Forest in Germany, Vosges Mountains and Massif Central in France - as well as in the Variscan basement of the Alps (Medaris \& Carswell, 1990; O’Brien \& Rötzler, 2003; Massonne \& O'Brien, 2003).

The peridotite body probably reached the subducted crust and then formed the metamorphic aureole (that existing in the proximities of Jubrique and in other sectors, Fig. 2, and Fig. 1 of Tubía et al. 2013 for a more complete location). During the exhumation of the UHP rocks a melting stage seems to have occurred, recorded by granitic inclusions in garnets from several zones (Ruiz Cruz \& Sanz de Galdeano, $2013,2014)$, and by the Carboniferous (>300 Ma) zircon domains with oscillatory zoning (Fig. 11C-C' and D-D'), which appear as fractured cores, reflecting their origin inherited from the feeder in the granitic rock studied here.

The data presented here demonstrate that the peridotites and the overlying crustal rocks of the Jubrique unit were locally exposed at the surface and partially eroded during the late Carboniferous? -Permian; i.e. during the late or post-Variscan Orogeny. During the Permian, major magmatic activity occurred, as reflected in the MF. This formation included relics of the previous aureole and of the overlying sequence, as can be seen in the Hacho Unit from Ceuta. Immediately afterwards the MDF and the carbonates were deposited.

The MF and the gneissic levels included in the MDF with an age of $269 \pm 9$ Ma can be related to the beginning of a major process of extension, a prelude to the extension that continued during the Triassic, the Jurassic, and part of the Cretaceous in the Betics. Indeed, the deposit of the carbonates is interpreted as indicative of the generalized marine transgression, since marbles with this age are common to all the complexes of the Internal Zone. Particularly during the Triassic, a thick sedimentary sequence (at least $1000 \mathrm{~m}$ thick) formed mainly by carbonates, was deposited in the basin currently corresponding to the Alpujarride Complex and the Nevado-Filabride.

The Alpine deformations regionally began during the late Cretaceous and continued till the Miocene. The Internal Zone was situated to the east of their 
present position at the beginning of this process. Then the collision/subduction and superposition of the several tectonic units occurred, and also the westward tectonic drift of the Internal Zone (mainly during the early Miocene). In this process, the Jubrique unit, with the peridotites at the bottom, was superposed over Sierra de las Nieves as indicate by Dürr (1963), Sanz de Galdeano (1997), and many other authors. Mazzoli \& Martín Algarra (2011) and Mazzoli et al. $(2013,2014)$ describe in detail the characteristics of the overthrust of the peridotites over this sierra. The westward drifting caused the formation of the antiforms of the areas of the Sierras Bermeja, Palmitera, and Sierra Real, with the synforms situated in between, coevally with the opening of the Alboran Sea, the most western part of the Mediterranean.

Then, a new exhumation process affected Internal Zone, and clasts inherited from them, including peridotites, were deposited in the Millanas-Viñuela Fm. (Bourgois, 1972), late Aquitanian - early Burdigalian in age, approximately $20 \mathrm{Ma}$ ago (Sanz de Galdeano et al., 1993). The regional uplift continued till the present, giving way to the current situation.

\section{Conclusions}

To the north of Estepona and in the sector of Benahavis - Guadaiza, two former sedimentary formations (the MDF and the marbles), appear unconformably overlying a magmatic formation and the Ronda peridotites. The presence of acidic rocks intercalated in the MDF and providing a magmatic age of $\sim 270 \mathrm{Ma}$, constrains the age of this formation to the Permian. The undated marble formation overlying the MDF can be ascribed to the Triassic according to its stratigraphic position and by comparison with similar rocks from other units of the Internal Zone.

The identification of these unconformable formations is crucial in the discussion of the age of the exhumation of the Ronda Peridotites - that is, the peridotites reached the surface probably during the late Carboniferous, and clasts of peridotites are included in the MDF.

During the Mesozoic, the entire region underwent a process of extension and received major sedimentation, on the order of $1000 \mathrm{~m}$ in thickness, covering all the previous rocks, including the peridotites.
Later, during the Alpine cycle, the peridotites operate as an element situated at the bottom of the higher Alpujarride/Sebtide units (the Jubrique unit) and tectonically forming part of it, thrusting, for instance, the Sierra de las Nieves unit. A new process of uplift permitted the second exhumation of the peridotites.

\section{Acknowledgments}

The authors are grateful to P. Montero and F. Bea for the obtaining and processing of the isotopic data (this is the IBERSIMS publication $\mathrm{n}^{\circ} 31$ ) and to I. Sánchez for help in the SEM and CL study. Profs. J. Galindo-Zaldívar (Granada) and M. SánchezGómez (Jaén) improved and clarified the original manuscript. This study has received financial support from the Project CGL 2012-31872 (Ministerio de Economía y Competitividad, Spain). We are grateful to the direction of La Zagaleta who kindly permitted us the access to this property, facilitating the observations of the cuts in the new roads.

\section{References}

Afiri, A.; Gueydan, F.; Pitra, P.; Essaifi, A. \& Précigout, J. (2011). Oligo-Miocene exhumation of the BeniBousera peridotite through a lithosphere-scale extensional shear zone. Geodynamica Acta, 24: 49-60. http://dx.doi.org/10.3166/ga.24.49-60

Aldaya, F. (1981). Mapa Geológico de España, 1:50.000, hoja 1056 (Albuñol). Instituto Geológico y Minero de España, 39 p.

Acosta-Vigil, A.; Rubatto, D.; Bartoli, O.; Cesare, B., Meli, S.; Pedrera, A.; Azor, A. \& Tajcmanova, L. (2014). Age of anatexis in the crustal footwall of the Ronda peridotites, S Spain. Lithos, 210-211: 147-167. http://dx.doi.org/10.1016/j.lithos.2014.08.018.

Balanyá, J.C.; Azañón, J.M.; Sánchez-Gómez, M. \& García-Dueñas, V. (1993). Pervasive ductile extension, isothermal decompression and thinning of the Jubrique unit during the Paleogene times (Alpujarride Complex, Western Betics). Comptes Rendus de l'Académie des Sciences de Paris, 316, II: 1595-1601.

Balanyá, J.C. \& García-Dueñas. V. (1991). Estructuración de los Mantos Alpujárrides al W de Málaga (Béticas, Andalucía). Geogaceta, 9: 30-33.

Balanyá, J.C.; García-Dueñas, V.; Azañón, J.M. \& SánchezGómez, M. (1997). Alternating contractional and extensional events in the Alpujarride nappes of the Alboran Domain (Betics, Gibraltar Arc). Tectonics, 16: 226-238. http://dx.doi.org/10.1029/96TC03871

Black, L.P.; Kamo, S.L.; Allen, C.M.; Aleinikoff, J.A.; Davis, D.W.; Korsch, J.R. \& Foudolis, C. (2003). TEMORA 1: a new zircon standard for Phanerozoic $\mathrm{U}-\mathrm{Pb}$ geochronology. Chemical Geology, 200: 
155-170. http://dx.doi.org/10.1016/S0009-2541(03) 00165-7

Bourgois, J.; Chauve, P.; Magne, J.; Monnot, J.; Peyre, Y.; Rigo, E.; Rivière, M. (1972). La formation de las Millanas. Série burdigalienne transgressive sur les Zones Internes des Cordillères bétiques occidentales. (Région d'Alozaina-Tolox, province de Malaga, Espagne). Comptes Rendus de l'Académie des Sciences de Paris, 275: 169-172.

Bouybaouène, M.L.; Michard, A. \& Goffé. B. (1998). High- pressure granulites on top of the Beni Bousera peridotites, Rif belt, Morocco: a record of an ancient thickened crust. Bulletin de la Societé géologique de France, 169: 153-162.

Brueckner, H.K. \& Medaris, L.G. (Jr.) (2000). A general model for the intrusion and evolution of "mantle" peridotites in high-pressure and ultrahighpressure metamorphic terranes. Journal of Metamorphic Geology, 18: 123-133. http://dx.doi.org/ 10.1046/j.1525-1314.2000.00250.x

Chalouan, A.; Michard, A.; El Kadiri, Kh.; Negro, F.; Frizon de Lamotte, D.; Soto, J.I. \& Saddiqi, O. (2008). Chapter 5: The Rif Belt. In: Michard, A.; Saddiqi, O.; Chalouan, A.; Frizon de Lamotte, D. (Eds.). Continental Evolution: The Geology of Morocco. Structure, Stratigraphy, and Tectonics of the Africa-AtlanticMediterranean Triple Junction. Springer, 203-302. http://dx.doi.org/10.1007/978-3-540-77076-3_5

Chamón Cobos, C.; Estévez González, C. \& Piles Mateo, E. (1978). Mapa Geológico de España, 1:50.000, hoja 1072 (Estepona), Instituto Geológico y Minero de España, $37 \mathrm{p}$.

Connolly, J.A.D. (2009). The geodynamic equation of state: what and how. Geochemistry, Geophysics, Geosystems, 10, Q10014. http://dx.doi.org/10.1029/ 2009GC002540

Davies, G.R.; Nixon, P.H.; Pearson, D.G. \& Obata, M. (1993). Tectonic implications of graphitized diamonds from the Ronda, peridotite massif, southern Spain. Geology, 21: 471-474. http://dx.doi.org/ 10.1130/0091-7613(1993)021<0471:TIOGDF> 2.3.CO;2

Dickey, J.S. (Jr); Lundeen, M. \& Obata, M. (1979). Explanatory text to accompany the geologic map of the Ronda ultramafic complex, southern Spain. Map and chart series (Geological Society of America), 29: $1-4$.

Didon, J.; Durand Delga, M. \& Kornprobst, J. (1973). Homologies géologiques entre les deux rives du détroit de Gibraltar. Bulletin de la Societé géologique de France, 7, 15: 77-105. http://dx.doi.org/10.2113/ gssgfbull.S7-XV.2.77

Doblas, M. \& Oyarzun. R. (1989). "Mantle core complexes" and Neogene extensional detachment tectonics in the western Betic Cordilleras, Spain: an alternative model for the emplacement of the Ronda peridotite. Earth and Planetary Science Letters, 93: 76-84. http://dx.doi.org/10.1016/0012-821X(89)90185-4
Durand-Delga, M.; Fontboté, J.M. (1980). Le cadre structural de la Méditerranée occidentale. Mémoires du BRGM, 115: 67-85.

Dürr, S.H. (1963). Geologie der Sierra de Ronda und ihrer Südwestlichen Ausläufer (Andalousien). (1967). Thesis Univ. Bonn, 122 p. \& Geologica Romana, 6: 1-73.

Esteban, J.J.; Cuevas, J.; Tubía, J.M.; Sergeev, S. \& Larionov, A. (2011). A revised Aquitanian age for the emplacement of the Ronda peridotites (Betic Cordilleras, southern Spain). Geological Magazine, 148: 183-187. http://dx.doi.org/10.1017/S0016756810000737

Esteban, J.J.; Cuevas, J.; Vegas, N. \& Tubía, J.M. (2008). Deformation and kinematics in a melt-bearing shear zone from the Western Betic Cordilleras (Southern Spain). Journal of Structural Geology, 30: 380-393. http://dx.doi.org/10.1016/j.jsg.2007.11.010

García-Casco, A.; Sánchez-Navas, A. \& Torres-Roldán, R.L. (1993). Disequilibrium decomposition and breakdown of muscovite in high $\mathrm{P}-\mathrm{T}$ gneisses, Betic alpine belt, Southern Spain. American Mineralogist, 78: 158-177.

Garrido, C.J.; Gueydan, F.; Booth-Rea, G.; Précigout, J.; Hydas, K.; Padron-Navarta, J.A. \& Marchesi, C. (2011). Garnet lherzolite and garnet-spinel mylonite in the Ronda peridotite: vestiges of Oligocene backarc mantle lithospheric extension in the western Mediterranean. Geology, 39: 927-930. http://dx.doi. org/10.1130/G31760.1

Gómez-Pugnaire, M.T.; Rubatto, D.; Fernández-Soler, J.M.; Jabaloy, A.; López-Sánchez-Vizcaíno, V.; GonzálezLodeiro, F.; Galindo-Zaldívar, J. \& Padrón-Navarta, J.A. (2012). Late Variscan magmatism in the NevadoFilábride Complex: U-Pb geochronologic evidence for the pre-Mesozoic nature of the deepest Betic complex (SE Spain). Lithos, 146-147: 93-111. http:// dx.doi.org/10.1016/j.lithos.2012.03.027

Griffin, W.L.; O’Reilly, S.Y. \& Ryan, C.G. (1999). The composition and origin of sub-continental lithospheric mantle. In: Fei Y.; Bertka C.M.; Mysen B.O. (Eds.). Mantle Petrology: Field Observations and High-pressure Experimentation: A tribute to Francis R. (Joe) Boyd. The Geochemical Society, 13-45.

Hidas, K.; Booth-Rea, G.; Garrido, C.J.; MartínezMartínez, J.M.; Padrón-Navarta, J.A.; Konc, Z.; Giaconia, F.; Frets, E. \& Marchesi, C. (2013). Backarc basin inversion and subcontinental mantle emplacement in the crust: kilometre-scale folding and shearing at the base of the proto-Alborán lithospheric mantle (Betic Cordillera, southern Spain). Journal of the Geological Society, 170: 47-55. http:// dx.doi.org/10.1144/jgs2011-151

Kornprobst, J. (1962). Observations sur la série métamorphique de la Presqu'ile de Ceuta (Rif septentrional, Maroc). Comptes Rendus de l'Academie de Sciences de Paris, 255: 21-40.

Kornprobst, J. (1976). Signification structurale des péridotites dans l'orogène bético-rifain: arguments tirés de l'étude des détritus observés dans les sédiments paléozoïques. Bulletin de la Société Géologique de 
France, 18 (3): 607-618. http://dx.doi.org/10.2113/ gssgfbull.S7-XVIII.3.607

Liou, J.G.; Zhang, R.Y. \& Ernst, W.G. (2007). Very highpressure orogenic garnet peridotites. Proceedings of the National Academy of Sciences of the United States of America, 104: 9116-9121. http://dx.doi. org/10.1073/pnas.0607300104

Loomis, T.P. (1975). Tertiary mantle diapirism, orogeny and plate tectonics east of the Strait of Gibraltar. American Journal of Science, 275: 1-30. http:// dx.doi.org/10.2475/ajs.275.1.1

Lundeen, M.T. (1978). Emplacement of the Ronda peridotite, Sierra Bermeja, Spain. Geological Society of America Bulletin, 89: 172-180. http://dx.doi.org/ 10.1130/0016-7606(1978)89<172:EOTRPS >2.0.CO;2

Macpherson, J. (1868 \& 1874). Memoria sobre la estructura de la Serranía de Ronda. E.T.S.I.M., I-3, 745 and Imprenta de la Revista Médica. Cádiz, I-3:745.

Macpherson, J. (1879). Descripción de algunas rocas que se encuentran en la Serranía de Ronda. Anales de la Sociedad Española de Historia Natural, 8.

Massonne, H-J. \& O’Brien, P.J. (2003). The Bohemian Massif and the NW Himalaya. In: Carswell, D.A., \& Compagnoni, R. (Eds.). Ultrahigh pressure metamorphism. European Mineralogical Union Notes in Mineralogy, 5: 145-187.

Mazzoli, S. \& Martín-Algarra, A. (2011). Deformation partitioning during transpressional emplacement of a 'mantle extrusion wedge': the Ronda peridotites, western Betic Cordillera, Spain. Journal of the Geological Society, 168: 373-382. http://dx.doi.org/ 10.1144/0016-76492010-126

Mazzoli, S.; Martín-Algarra, A.; Reddy, S.M.; López Sánchez-Vizcaíno, V.; Fedele, L. \& Noviello, A. (2013). The evolution of the footwall to the Ronda subcontinental mantle peridotites: insights from the Nieves Unit (western Betic Cordillera). Journal of the Geological Society, 170: 385-402. http://dx.doi. org/10.1144/jgs2012-105

Mazzoli, S. \& Martín-Algarra, A. (2014). Comment on: "Localization of deformation and kinematic shift during the hot emplacement of the Ronda peridotites (Betic Cordilleras, southern Spain)" by J.M. Tubía, J. Cuevas, and J.J. Esteban, Journal of Structural Geology, 50 (2013), 148-160. Journal of Structural Geology, 60: 97-101. http://dx.doi.org/10.1016/j. jsg.2013.12.013

Medaris, L.G. (Jr) (1999). Garnet peridotite in Eurasian HP and UHP terranes: A diversity of origins and thermal histories. International Geology Review, 41: 799-815. http://dx.doi.org/10.1080/00206819909465170

Medaris, L.G. (Jr); Wang, H.F.; Mísař, Z. \& Jelínek, E. (1990). Thermobarometry, diffusion modelling and cooling rates of crustal garnet peridotites: Two examples from the Moldanubian zone of the Bohemian Massif. Lithos, 25: 189-202. http://dx.doi.org/ 10.1016/0024-4937(90)90014-R
Medaris, L.G. (Jr.) \& Carswell, D.A. (1990). The petrogenesis of $\mathrm{Mg}-\mathrm{Cr}$ garnet peridotites in European metamorphic belts. In: Carswell, D.A. (Ed.). Eclogite facies rocks. New York: Chapman and Hall, 260-290.

Michard, A.; Goffé, B.; Bouybaouene, M. \& Saddiqi, O. (1997). Late Variscan-Mesozoic thinning in the Alboran domain: metamorphic data from the northern Rif, Morocco. Terra Nova, 9: 171-174. http://dx.doi. org/10.1046/j.1365-3121.1997.d01-24.x

Montel, J.M.; Kornprobst, J. \& Vielzeuf, D. (2000). Preservation of old U-Th-Pb ages in shielded monazite: example from the Beni Bousera Hercynian kinzigites (Morocco). Journal of Metamorphic Geology, 18: 335-342. http://dx.doi.org/10.1046/ j.1525-1314.2000.00261.x

Nieto, J.M.; Puga, E. \& Díaz de Federico, A. (2000). Late Variscan pyroclastic rocks from theMulhacén Complex (Betic Cordillera, Spain). In: Leyrit, H., Montenat, Ch. (Eds.).Volcaniclastic Rocks, from Magmas to Sediments. Gordon and Breach Science Publishers, 217-224.

O'Brien, P.J. (2000). The fundamental Variscan problem: High-temperature metamorphism at different depths and high-pressure metamorphism at different temperatures. In: Franke, W.; Haak, V.; Onken, O. \& Tanner, D. (Eds.). Orogenic Processes: Quantification and Modelling in the Variscan Belt. Geological Society of London, Special Publication, 179: 369-386. http:// dx.doi.org/10.1144/GSL.SP.2000.179.01.22

O’Brien, P.J. \& Rötzler, J. (2003). High-pressure granulites: Formation, recovery of peak conditions, and implications for tectonics. Journal of Metamorphic Geology, 21: 3-20. http://dx.doi.org/10.1046/ j.1525-1314.2003.00420.x

Olmo Sanz, A. del; Pablo Macía, J.G de; Aldaya Valverde, F.; Campos Fernández, J.; Chacón Montero, J.; García Dueñas, V.; García Rossell, L.; Sanz de Galdeano, C.; Orozco Fernández, M. \& Torres Roldán, R. (1987). Mapa Geológico de España, 1:50.000, hoja 1064 (Cortes de la Frontera). Instituto Geológico y Minero de España. 55 pp.

Orueta, D. (1917). Estudio geológico y petrográfico de la Serranía de ronda. Láminas, mapas y cortes geológicos. Memorias del Instituto Geológico de España, 571 pp.

Piles, E.; Chamón Cobos, C. \& Estévez-González, C. (1978). Mapa y memoria explicativa de la hoja 1065 (Marbella) del Mapa Geológico Nacional a escala 1:50.000. Instituto Geológico y Minero de España, 65 pp.

Piles Mateo, E.; Estévez González, C.; Barba Martín, A.; Crespo, V.; Aguilar, V. \& Reyes, J.L. (1978). Mapa Geológico de España, 1:50.000, hoja 1066 (Coín Instituto Geológico y Minero de España, 71 pp.

Platt, J.P.; Argles, T.W.; Carter, A.; Kelley, S.P.; Whitehouse, M.J. \& Lonergan, L. (2003). Exhumation of the Ronda peridotite and its crustal envelope: constraints from thermal modelling of a P-T-time array. 
Journal of the Geological Society, 160: 655-676. http://dx.doi.org/10.1144/0016-764902-108

Platt, J.P.; Behr, W.M.; Johanesen, K. \& Williams, J.R. (2013). The Betic-Rif Arc and Its Orogenic Hinterland: A Review. Annual Review of Earth and Planetary Sciences, 41: 313-357. http://dx.doi.org/10.1146/ annurev-earth-050212-123951

Platt, J.P. \& Whitehouse, M.J. (1999). Early Miocene high-temperature metamorphism and rapid exhumation in the Betic Cordillera (Spain): evidence from U-Pb zircon ages. Earth and Planetary Science Letters, 171: 591-605. http://dx.doi.org/10.1016/ S0012-821X(99)00176-4

Précigout, J.; Gueydan, F.; Garrido, C.J.; Cogné, N. \& Booth-Rea, G. (2013). Deformation and exhumation of the Ronda Peridotite (Spain). Tectonics, 32: 1011-1025. http://dx.doi.org/10.1002/tect.20062

Priem, H.N.A.; Boelrijk, E.H.; Hebeda, I.S. \& Oen, E.A.Th. (1979). Isotopic dating of the emplacement of the ultramafic masses in the Serrania de Ronda, southern Spain. Contributions to Mineralogy and Petrology, 70: 103-109. http://dx.doi.org/10.1007/BF00371876

Reisberg, L.; Zindler, A. \& Jagouts, E. (1989). Further $\mathrm{Sr}$ and $\mathrm{Nd}$ isotopic results from peridotites of the Ronda ultramafic complex. Earth and Planetary Science Letters, 96: 161-180. http://dx.doi.org/ 10.1016/0012-821X(89)90130-1

Reuber, I.; Michard, A.; Chalouan, A.; Juteau, T. \& Jermoumi, B. (1982). Structure and emplacement of the alpine-type peridotites from Beni Bousera, Rif, Morocco: a polyphase tectonic interpretation. Tectonophysics, 82: 231-251. http://dx.doi.org/10.1016/ 0040-1951(82)90047-6

Rossetti, F.T.; Theye, F.; Lucci, M.L.; Bouybaouene, A.; Dini, A.; Gerdes, A.; Phillips, D. \& Cozzupoli, D. (2010). Timing and modes of granite magmatism in the core of the Alboran Domain, Rif chain, northern Morocco: Implications for the Alpine evolution of the western Mediterranean. Tectonics, 29, TC2017. http://dx.doi.org/10.1029/2009TC002487

Ruiz Cruz, M.D. \& Bentabol, M. (2014). Nitrogenbearing cordierite and tobelite in meta-rhyolites from the Ceuta zone (Rif Belt, Spain): Evidence for mobility of nitrogen in the continental crust. The Canadian Mineralogist, 51: 689-704. http://dx.doi. org/10.3749/canmin.51.5.689

Ruiz Cruz, M.D. \& Sanz de Galdeano, C. (2009). Exsolution microstructures in $\mathrm{NH}_{4}$-bearing muscovite and annite in gneisses from the Torrox area, Betic Cordillera, Spain. The Canadian Mineralogist, 47: 107-128. http://dx.doi.org/10.3749/canmin.47.1.107

Ruiz Cruz, M.D. \& Sanz de Galdeano, C. (2012). Possible genetic relationships between granulites and orthogneisses from Ceuta (Spain): Geotectonic implications. Geotemas, 13: 1096-1099.

Ruiz-Cruz, M.D. \& Sanz de Galdeano, C. (2013). Coesite and diamond inclusions, exsolution microstructures and chemical patterns in ultrahigh pressure garnet from Ceuta (Northern Rif, Spain). Lithos, 177: 184-206. http://dx.doi.org/10.1016/j.lithos.2013.06.004

Ruiz Cruz, M.D. \& Sanz de Galdeano, C. (2014). Garnet variety and zircon ages in UHP meta-sedimentary rocks from the Jubrique zone (Alpujárride Complex, Betic Cordillera, Spain): Evidence for a pre-Alpine emplacement of the Ronda peridotite. International Geology Review, 56: 845-868. http://dx.doi.org/10. 1080/00206814.2014.904759

Ruiz Cruz, M.D.; Sanz de Galdeano, C. \& Garrido, C. (2011). EBSD-based identification and quantification of diamond from the Rif gneisses (Spain and Morocco): Economic implications. Economic Geology, 106: 1241-1249. http://dx.doi.org/10.2113/ econgeo.106.7.1241

Ruiz Cruz, M.D.; Sanz de Galdeano, C. \& Massonne, H.J. (2012). First record of lonsdaleite in the Betic cordillera, Spain. Geotemas, 13: 1100-1103.

Sánchez-Gómez, M.; Azañón, J.M.; García-Dueñas, V. \& Soto, J.I. (1999). Correlation between metamorphic rocks recovered from Site 976 and the Alpujárride rocks of the western Betics. Proccedings of the Ocean Drilling Program, Scientific results, 161: 307-317. http://dx.doi.org/10.2973/odp.proc.sr.161.225.1999

Sánchez-Gómez, M.; Balanyá, J.C.; García-Dueñas, V. \& Azañón, J.M. (2002). Intracrustal tectonic evolution of large lithosphere mantle slabs in the western end of the Mediterranean orogen (Gibraltar Arc). Journal of the Virtual Explorer, 8: 107-130. http://dx.doi. org/10.3809/jvirtex.2002.00054

Sánchez-Gómez, M.; García-Dueñas, V. \& Muñoz, M. (1995a): Relations structurales entre les Péridotites de Sierra Bermeja et les unités alpujarrides sousjacentes (Benahavís, Ronda, Espagne). Comptes Rendus de l'Académie des Sciences de Paris, 321, Série II: 885-892.

Sánchez-Gómez, M.; García-Dueñas, V.; Muñoz, M. \& Balanyá, J.C. (1995b). Relación estructural de los cuerpos peridotíticos situados al Norte y al Sur del Estrecho de Gibraltar. Geogaceta, 17: 135-137.

Sánchez-Rodríguez, L.; Gebauer, D. (2000). Mesozoic formation of pyroxenites and gabbros in the Ronda area (southern Spain), followed by Early Miocene subduction metamorphism and emplacement into the middle crust: $\mathrm{U}-\mathrm{Pb}$ sensitive high-resolution ion microprobe dating of zircon. Tectonophysics, 316: 19-44. http:// dx.doi.org/10.1016/S0040-1951(99)00256-5

Sanz de Galdeano, C. (1990). Geologic evolution of the Betic Cordilleras in the Western Mediterranean, Miocene to the present. Tectonophysics, 172:107-119. http://dx.doi.org/10.1016/0040-1951(90)90062-D

Sanz de Galdeano, C. (1997). La Zona Interna BéticoRifeña (Antecedentes, unidades tectónicas, correlaciones y bosquejo de reconstrucción paleogeográfica). Monográfica Tierras del Sur. Universidad de Granada, $316 \mathrm{pp}$. 
Sanz de Galdeano, C.; Andreo, B.; García-Tortosa, F.J. \& López-Garrido, A.C. (2001). The Triassic palaeogeographic transition between the Alpujarride and Malaguide complexes, Betic-Rif Internal Zone (S Spain, N Morocco). Palaeogeography, Palaeoclimatology, Palaeoecology, 167: 157-173. http:// dx.doi.org/10.1016/S0031-0182(00)00236-4

Sanz de Galdeano, C. \& López-Garrido, A.C. (2014). La ventana tectónica de Albuñol: estratigrafía y estructura (Complejo Alpujárride, Zona Interna Bética, provincia de Granada. Revista de la Sociedad Geológica de España, 27 (1): 287-299.

Sanz de Galdeano, C.; Serrano, F.; López Garrido, A.C. \& Martín Pérez JA (1993). Palaeogeography of the Late Aquitanian-Early Burdigalian Basin in the Western Betic Internal Zone. Geobios, 26: 43-55. http:// dx.doi.org/10.1016/S0016-6995(93)80005-C

Tubía, J.M. (1985). Estructura de los Alpujárrides occidentales: cinemática y condiciones de emplazamiento de las peridotitas de Ronda. Tesis Doctoctal, Universidad del País Vasco. 311pp. (Also in Boletín Geológico y Minero, 99 (2, 3, 4 \& 5).

Tubía, J.M. (1994). The Ronda peridotites (Los Reales nappe): an example of the relationship between lithospheric thickening by oblique tectonics and late extensional deformation within the Betic Cordillera (Spain). Tectonophysics, 238: 381-398. http:// dx.doi.org/10.1016/0040-1951(94)90065-5

Tubía, J.M. \& Cuevas, J. (1986). High-temperature emplacement of the Los Reales peridotite nappe (Betic Cordillera, Spain). Journal of Structural Geology, 8: 473-488. http://dx.doi.org/10.1016/01918141(86)90064-7

Tubía, J.M. \& Cuevas, J. (1987). Structures et cinématique liées à la mise en place des péridotites de Ronda (Cordillères Bétiques, Espagne). Geodinamica Acta, 1: 59-69. http://dx.doi.org/10.1080/09853111.1987.1 1105125

Tubía, J.M.; Cuevas, J. \& Esteban, J.J. (2003). Interpretación geodinámica del metamorfismo de ultra-alta presión en las peridotitas de Ronda. Geogaceta, 34: 47-50.

Tubía, J.M.; Cuevas, J. \& Esteban, J.J. (2013). Localization of deformation and kinematic shift during the hot emplacement of the Ronda peridotites (Betic Cordilleras, southern Spain). Journal of Structural Geology, 50, 148-160. http://dx.doi.org/10.1016/j. jsg.2012.06.010

Tubía, JM.; Cuevas, J. \& Gil Ibarguchi, J.I. (1997). Sequential development of the metamorphic aureole beneath the Ronda peridotites and its bearing on the tectonic evolution of the Betic Cordillera. Tectonophysics, 279: 227-252. http://dx.doi.org/10.1016/ S0040-1951(97)00124-8

Tubía, J.M.; Navarro-Vila, F. \& Cuevas, J. (1993). The Maláguide-Los Reales Nappe: an example of crustal thinning related to the emplacement of the Ronda peridotites (Betic Cordillera). Physics of the Earth and Planet Interiors, 78: 343-354. http://dx.doi.org/ 10.1016/0031-9201(93)90165-6

Van der Wal, D. \& Bodinier, J.L. (1996). Origin of the recrystallisation front in the Ronda peridotite by $\mathrm{km}$ scale pervasive porous melt flow. Contributions to Mineralogy and Petrology, 122: 387-405. http:// dx.doi.org/10.1007/s004100050135

Vissers, R.L.M.; Platt, J.P. \& Van der Wal, D. (1995). Late orogenic extension of the Betic Cordillera and the Alboran Domain: A lithospheric view. Tectonics, 14: 786-803. http://dx.doi.org/10.1029/95TC00086

Wildi, W. (1983). La chaîne tello-rifaine (Algérie, Maroc, Tunisie): structure, stratigraphie et évolution du Trias au Miocène. Revue de Géologie Dynamique et de Géographie Physique, 24: 201-297.

Whitney, D.L. \& Evans, B.W. (2010). Abbreviations for names of rock-forming minerals. The American Mineralogist, 95: 185-187. http://dx.doi.org/ 10.1038/304226a0.2138/am.2010.3371

Zeck, H.P. \& Whitehouse, M.J. (2002). Repeated age resetting in zircons from Hercynian-Alpine polymetamorphic schists (Betic-Rif tectonic belt, S Spain) - A U-Th-Pb ion microprobe study. Chemical Geology, 182: 275-292. http://dx.doi.org/10.1016/ S0009-2541(01)00296-0

Zindler, A.; Staudigel, H.; Hart, S.R.; Endres, R. \& Goldstein, S. (1983). Nd and Sr isotopic study of a mafic layer from Ronda ultramafic complex. Nature, 304: 226-230. http://dx.doi.org/10.1038/304226a0 